DEPARTMENT OF FOOD AND RESOURCE ECONOMICS

UNIVERSITY OF COPENHAGEN

IFRO Working Paper

Food Standards are Good

- for Middle-Class Farmers

Henrik Hansen

Neda Trifković 


\section{IFRO Working Paper 2013 / 19}

Food Standards are Good - for Middle-Class Farmers

Authors: Henrik Hansen, Neda Trifković

www.ifro.ku.dk/english/publications/foi series/working papers/

Department of Food and Resource Economics (IFRO)

University of Copenhagen

Rolighedsvej 25

DK 1958 Frederiksberg DENMARK

www.ifro.ku.dk 


\title{
Food Standards are Good - for Middle-Class Farmers
}

\author{
Henrik Hansen \\ Department of Economics, Faculty of Social Sciences, University of Copenhagen
}

Neda Trifković

Department of Food and Resource Economics, Faculty of Science, University of

Copenhagen 


\begin{abstract}
We estimate the causal effect of food standards on Vietnamese pangasius farmers' wellbeing measured by per capita consumption expenditure. We estimate both the average effects and the local average treatment effects on poorer and richer farmers by instrumental variable quantile regression. Our results indicate that large returns can be accrued from food standards, but only for the upper middle-class farmers, i.e., those between the $50 \%$ and $85 \%$ quantiles of the expenditure distribution. Overall, our result points to an exclusionary impact of standards for the poorest farmers while the richest do not apply standards because the added gain is too small.
\end{abstract}

Key words: food standards, pangasius, instrumental variable, quantile regression, Vietnam, Asia

JEL codes: Q13, Q18, D02, D13, D31 


\section{Acknowledgements}

The authors would like to thank the staff of the School of Economics and Business Administration and the College of Aquaculture and Fisheries at Can Tho University, Vietnam. We thank Ydun Donahoe, Mr Le Dang Trung, Ms Thi Minh Thai, Miss Le Canh Bich Tho, Mr Nguyen Ho Anh Khoa and student enumerators from Can Tho University for helping with the organization and management of the fieldwork. Most sincere thanks go to all the persons from pangasius sector that we interviewed because without them the research for this paper would not have been possible. We also thank the participants of AEM 7650: Development Microeconomics Graduate Research Seminar at Cornell University for comments on an early draft of this paper. N. Trifković acknowledges gratefully funding from Oticon Foundation, Augustinus Foundation and Solarfonden in addition to LIFE PhD scholarship awarded by the Faculty of Life Sciences, University of Copenhagen. The usual caveats apply. 


\section{Introduction}

To participate in global value chains producers need to fulfill requirements of food quality and safety regulation of destination markets. Typically, it is not sufficient to comply with the public regulation in the destination countries as foreign market access depends on the ability of exporters to follow private or voluntary food standards. ${ }^{1}$ The impact of food standards on the wellbeing of farmers in developing countries has been debated intensively, as the effect may be both positive and negative. Introduction of voluntary standards in a particular agri-food sector is associated with high compliance costs for farmers and this may marginalize the poorest (Henson \& Jaffee, 2008; Reardon, Barrett, Berdegué, \& Swinnen, 2009). Food standards may also induce negative externality effects on poor farmers because the inability to comply with food safety and quality standards can result in selling to unprofitable markets (Reardon \& Farina, 2002). However, it is similarly possible for small-scale producers to benefit from food standards. Application of standards can reduce rural poverty because of increased local demand (Maertens \& Swinnen, 2009) and farmers who succeed in complying with private standards can benefit through several channels, either (i) higher net production revenues (Asfaw, Mithöfer, \& Waibel, 2010b), (ii) better employment conditions, such as higher wages and longer employment periods (Colen, Maertens, \& Swinnen, 2012), or (iii) better production practices and health (Asfaw, Mithöfer, \& Waibel, 2010a).

In analyzing the direct impact of food standards on farmers' livelihoods, most of the literature has focused on average impacts. While the average gain from standards is surely interesting, there is, in our view, a case for believing that the gain is unevenly distributed across households of different socio-economic status. First of all, we argue that in rural markets with credit constraints or high financing costs due to information asymmetries, a positive impact of standards is only attributable to farmers in the upper segments of the income or wealth distribution because of excessive financing costs for the poorer farmers. This argument is based on findings in previous studies that show how adoption of standards is to a large extent determined by households' endowments of capital, resulting in a wealth threshold above which application of standards becomes

\footnotetext{
${ }^{1}$ For an overview of categories of food standards, see Henson and Humphrey (2010)
} 
beneficial (see, e.g. Asfaw et al., 2010b; Kersting \& Wollni, 2012). Similarly, Neven et al. (2009) report a restraining capital vector for entrance into the supermarket supply chain in Kenya. Their results illustrate that the key suppliers of Kenyan supermarkets are medium-sized, fast-growing commercial farms that hinder participation of small farms and institute the new middle-class. Based on these observations, we believe that obtaining evidence on the impact of standards at different welfare levels can assist in better agricultural policy design.

The decision to adopt food standards can be framed as a case of new technology adoption. Underpinned by concerns about economic growth and poverty reduction, technology adoption models have analyzed how new plant varieties or production techniques are adopted by farmers (Conley \& Udry, 2010; Foster \& Rosenzweig, 1995; Suri, 2011). However, just as for the food standards literature, a focus on mean impact has left out the possibility of heterogeneous wealth impacts in the adoption of new technologies. We therefore believe our analysis of the distribution of the gain from applying food standards on farmers' wellbeing is also contributing to the technology adoption literature.

We estimate the distributional impact of food standards on consumption expenditure using an original dataset from the Vietnamese pangasius value chain. ${ }^{2}$ To overcome the pervasive endogeneity problems present in this kind of impact estimations with substantial self-selection we use an instrumental variable quantile regression model developed by Abadie et al. (2002) to estimate the causal effect of food standards on farmers in selected expenditure quantiles. In order to substantiate our econometric findings and further enrich our understanding of the farmer's situation and decision problem, we complement the statistical analysis with insights from our price data and qualitative interviews with key stakeholders.

\footnotetext{
${ }^{2}$ Other commercial names are also used for pangasius, such as catfish, basa, swai, iridescent shark and sutchi.
} 
The results of our study can be summarized as follows. We find a positive average impact of food standards on household wellbeing: applying standards leads to an average increase in monthly per capita consumption expenditure of about $50 \%$ in our most conservative specification. When we allow for varying impacts across the expenditure distribution, we find small and insignificant effects for the poorest half while there are large positive effects for the upper middle-class, defined as households from around the median of the distribution and upwards, but excluding the upper $10-15 \%$ tail. The gain for the upper middle-class is an increase in consumption expenditure of around $65 \%$ in our most conservative estimation. While the insignificant impact of standards on the poorest half of the farmers is clearly the main result, the insignificant impact of adopting standards for the $10-15 \%$ wealthiest farmers is also interesting and we argue that the finding is not simply a statistical coincidence. The estimated distribution of the impact of adoption of standards is the outcome of two different conditions: (i) For the poorest farmers there is no gain because of the high costs of financing the investment, and (ii) For the wealthiest farmers there is no gain because they are already able to get high prices on their fish, partly because they produce fish of high quality and partly because they have good working relations with the processors. The overall outcome is that application of food standards in the Vietnamese pangasius sector is benefitting the upper middle-class directly, while the benefits for the poorer segment are either absent or, at best, second order labor market effects as described in Maertens and Swinnen (2009) and Colen et al. (2012).

The paper is structured as follows: In Section 2 we briefly review relevant literature on the impact of standards in developing countries. In Section 3, we describe the Vietnamese pangasius sector and provide a brief review of trends in food safety standards. Section 4 presents the survey data and key descriptive statistics, while Section 5 lays out our econometric approach to estimating the welfare impact of food standards and shows the results. We discuss and compare our results with previous studies in Section 6, while we offer a brief conclusion in Section 7. 


\section{Standards in developing countries}

The literature suggests that the effects of standards on smallholder producers from developing countries are ambiguous. In an overview of the literature on smallholder participation in high-standards export sectors in Africa, Maertens et al. (2012) conclude that the impact of standards is both sector- and country-specific. An important concern is that standards contribute to exclusion of the poorest farmers who, due to weak managerial and capital endowments, fail to comply with strict requirements. The costs of implementing standards at the farm level vary across individual farmers, products, sectors and geographical location, as conditioned by economies of scale or location-specific factors. Further, non-compliance with standards is linked with exclusion of farmers from high-value export sectors and higher inequality in several studies (Farina \& Reardon, 2000; Reardon, Codron, Busch, Bingen, \& Harris, 1999).

Conversely, standards can improve the financial position of farmers who succeed in complying with standards (Giovannucci \& Ponte, 2005; Maertens \& Swinnen, 2009; Reardon et al., 2009). After the initial investments, standards can bring positive financial returns to farmers as they improve access to (and the survival in) new markets, quality and safety product attributes and competitiveness (Henson \& Reardon, 2005; Reardon et al., 1999). The key determinants of the farmers' ability to comply with standards are establishment size, ownership of production and household assets, social capital, information access and external assistance (Asfaw et al., 2010b; Henson, Masakure, \& Cranfield, 2011; Kersting \& Wollni, 2012; Reardon et al., 2009). Previous studies have shown a significant relationship between adoption of standards and farm size, the level of physical, social and human capital, weak credit access and isolation from producer associations (Asfaw et al., 2010b; Narrod et al., 2009; Okello \& Swinton, 2007). Thus, it is typically the better-off farmers who apply standards. Similar results hold for the inclusion of smallholders in retail marketing channels and contract farming schemes (Key \& Runsten, 1999; Neven et al., 2009; Reardon et al., 2009). 
Previous studies of the impact of standards on rural households mainly focus on average effects, thus failing to identify the exact wealth interval at which the impact of standards becomes significant. A somewhat comparable strand of literature on poverty interventions in developing countries shows that the effect of development interventions is usually heterogeneous, i.e., some groups benefit more than others. For example conditional cash transfers do not have the same effect on different income groups (Galiani \& McEwan, 2013) and richer households tend to benefit more from rural infrastructure improvements than poorer ones (Khandker, Samad, Ali, \& Barnes, 2012). Benefits from participating in high-value export sectors are usually reserved for wealthier households, whether through choosing better marketing channels or contracts (Key \& Runsten, 1999; Minten, Randrianarison, \& Swinnen, 2009; Neven et al., 2009; Rao \& Qaim, 2011). Furthermore, poor farm-households in developing countries exit export sectors while large companies and developing country elites appropriate rents in export value chains (Reardon et al., 1999). These examples illustrate that it is of critical importance to assess the effect of standards at different welfare levels as failing to do so could discount the potential effect of standards on inequality in rural areas.

\section{The pangasius sector in Vietnam}

The Vietnamese pangasius sector started developing from household farms that cultivated freshwater species Pangasius bocourti (Mekong catfish, ca basa in Vietnamese) and Pangasianodon hypophthalmus (striped catfish, ca tra) in the Mekong River Delta (MRD). These species have been farmed in cages and small ponds since the beginning of the 1960s. Over the last decade the farming of striped catfish has taken primacy over the basa variety as it proved easier to spawn and faster growing. In addition, its quality attributes are better (Phuong \& Oanh, 2010), and now it accounts for almost all of farmed pangasius in Vietnam.

(a) Production and export

Pangasius was first exported at the beginning of the 1990s, to Australia. Soon after that, Asian countries, the US, and the EU followed (Tuan, 2003). Starting in 2007, new markets emerged, notably Russia and Ukraine, but also South America and the Middle 
East. With global proliferation of food quality and safety standards, the choice of export destination depends on product quality whereby the certified, highest quality products are sold in Western markets.

Vietnamese production of pangasius grew from 40,000 metric ton in 1997 to over one billion metric ton in 2009 (FAO, 2012). In terms of production, pangasius accounted for more than $40 \%$ of Vietnam's total aquaculture value, with a farm-gate value of almost two USD billion in 2008 (FAO, 2010). The average annual growth rate in value terms was 37\% in the period 1997-2008. A record growth of 63\% was marked between 2006 and 2007, while production output and value decreased by 16\% between 2008 and 2009 (Figure 1). The export value decreased by $7.5 \%$ while export quantity decreased by $5 \%$ in the same year.

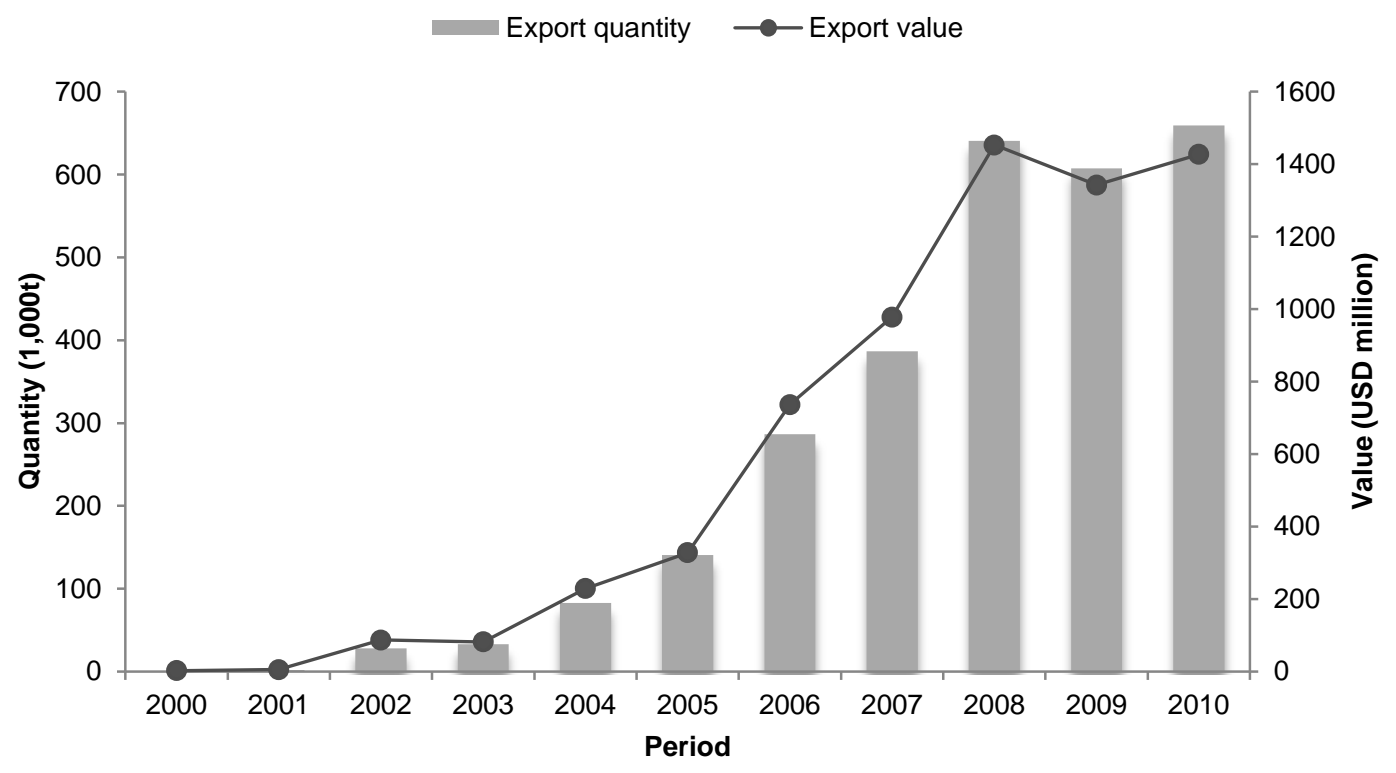

Figure 1. Quantity and value of pangasius export 2000-2010

Source: Nguyen (2010) and Dzung (2011)

The export decline coupled with fluctuations in input and farm-gate prices brought financial difficulties to pangasius farmers. It is believed that about $70 \%$ of all pangasius farmers had negative returns in 2009 (Belton, Little, \& Sinh, 2011) and depending on 
location, between 30\% and 50\% of pangasius farmers have stopped producing since 2009 (Vietnamnews, 2011; Vina Seafood, 2009). To cope with the losses in production, some farmers started to lease or sell their ponds to processing companies while others moved to wage labor on other farms, or to agriculture. Some farmers would occasionally shift to fingerling production or production of fish species that are demanded in the domestic market. The fluctuations in demand for pangasius, partly coupled with high levels of uncertainty in retail markets are brought by claims about poor quality of the fish and unsustainable production practices in European media and NGO initiatives (Bush \& Duijf, 2011). As a response to tight market conditions, the pangasius sector has seen a spread of quality and safety standards both at the farm and the processor level.

(b) Value chain, product quality and standards

Ensuring satisfactory product quality and safety requires close monitoring of activities during primary production and processing. Two approaches of retailers and international traders can be observed in this regard. The first approach is seen with retailers and traders who have developed their own internal standards and certification schemes, which include visits at production and processing sites and quality inspection of products. The second approach is seen with retailers who require that producers and processors obtain internationally recognized certificates through systems such as GlobalGAP, BAP or BRC. ${ }^{3}$ In this case, certification substitutes for the active involvement of retailers in production and distribution monitoring.

Standards such as GlobalGAP and BAP have primacy at the farm-level of the pangasius value chain. GlobalGAP is presently the leading certification system in continental Europe, while retail chains in the US, Canada and UK favor BAP certification. In Vietnam, some $45 \%$ of the pangasius farming area (2,805 ha) is certified (VASEP, 2011). There are currently 49 enterprises with GlobalGAP certification, while 103 farms have been, or are being, certified by different sustainability standards. Two pangasius processing plants, one farm and one feed supplier are BAP certified (GAA, 2011).

\footnotetext{
${ }^{3}$ GlobalGAP: The Global Partnership for Good Agricultural Practice, previously known as EurepGAP; BAP: Best Aquaculture Practices; BRC: British Retail Consortium Global Standard for Food Safety.
} 
In the pangasius value chain the process of exchange starts by the orders received from buyers, primarily foreign retailers, who communicate their purchase specifications to international traders, wholesalers, or directly to processing companies. In fulfilling orders, processors opt for sourcing from own farms (estate farms) or from contract farms. Alternatively, farmers inform processors that they have particular quantity of fish to sell. Production on estate farms allows for the greatest degree of control over production methods. By sourcing the fish from multiple parties, processing companies can supply a range of qualities and prices, while ensuring an ability to flexibly respond to changes in demand over time.

As sales of pangasius to processing companies are not conditioned by compliance with standards, both spot-market purchases from independent farmers and contract production involve product testing for quality and safety verification. Technicians employed by processing companies check the quality and safety of unprocessed fish at the farm and based on the inspection results the company decides whether to complete the purchase. The quality inspections consist of size and flesh color checks, while the safety inspections include tests for the presence of antibiotic residues and fish diseases. At this point, the farmgate price is determined, reflecting the overall quality parameters of fish. The fish is tested again at the point of delivery to the processing plant. Just after the processing and before they are shipped abroad, products are inspected by the authorities (NAFIQAVED - National Fisheries Quality Assurance and Veterinary Directorate). In case a processing company sells to any of the retail chains it is customary for retailers to pay visits to processing facilities and farms to inspect not only the final product but also the production process. Guided by commercial concerns about their marketing image, retailers are found to be regulating the nature of processes upstream in the value chain.

In line with the new regulation on environmental protection in Vietnam, farms that supply pangasius have to be located in areas designated for aquaculture so processors in principle give advantage to such farms. Among other factors that determine the supplier choice, quality and food safety requirements of consumers translated into retailers' specifications play a prominent role. Export markets such as the EU and the US impose 
very strict safety and quality requirements for imported products (Jaffee \& Masakure, 2005). In addition to regulation on microbiological contamination and chemical residues, such as residues of veterinary drugs, actors in these markets are requesting that the fish be farmed in a way that is respectful for the environment, workers, and their communities. A failure to follow quality and safety regulation of export markets results in product detention or rejection at the border after which the consignment is destroyed or dispatched to a less demanding market, at the exporter's expense. Restrictiveness is not so high in the Asian, Middle-Eastern, and Eastern European markets, but it is still judged to be more rigorous than the Vietnamese domestic market.

In conjunction with the implementation of standards, processing companies have a traceability system implemented on their farms and they also engage own technicians to implement traceability systems on contract farms. The tracing records identify not only the farmers who supplied the unprocessed fish but also all the input sources, input use, and disease treatments administered at the farm. Any problems detected at the retail level can in this way be traced to the farmer.

(c) On-farm requirements for application of standards

The application of standards on farms entails ensuring compliance with national legislation and specific food quality and safety regulation of export markets. Farmers need to establish traceability on their farm, which means that they have documentation for all farm inputs. The production technology also varies with the application/nonapplication of standards. Specifically, the technology is more demanding when standards are applied, as farms applying standards must have sedimentation basins, which serve to collect sludge from fishponds before the effluent is released from the farm. The size of sedimentation basins must be around $20 \%$ of production area, implying lower output per land unit (all else equal). Due to increased complexity, the amount of labor spent on farming and the use of other farm inputs also differ with the application/non-application of standards. Farmers need to attend trainings or hire qualified personnel and consultants who will advise them about standards and train farm workers. Furthermore, when producing under standards, farmers must pay more attention to the production inputs because they need to comply with requirements of the standard: better feed and 
fingerlings, purchased from a certified supplier, and approved medicines and cleaning agents. ${ }^{4}$ There are also different variable costs because production under standards requires inspection of inputs and intensive record keeping, maintenance of cleaning and disinfection schedules, and specialist application of medicines. In addition, after successful implementation of standards, farmers can opt for certification, which requires auditing through a third party, where as a rule the producer has to bear the full cost.

Despite the changes in input requirements for land, labor, and intermediate inputs it is not certain that productivity decreases because the implementation of standards entails improved management of the production process as farmers use improved inputs and technologies, which in turn can lead to less disease occurrence, higher-quality products, and, thus, less product rejection from processors.

Implementation of standards requires initial investment in equipment and modifications on farms (e.g., sludge aerators, filters, drainage equipment or sedimentation basins) whereby farmers incur a specific cost when they switch from traditional production to standards. The initial costs are often too large to be financed by retained earnings or other accumulated income and the processors do not provide loans or credit for the investment. Hence, the credit market will influence the decision to adopt standards and the net gain from the adoption. Even though the application of standards puts the financial pressure on pangasius farmers, there are no mechanisms to guarantee price premium for standards (Belton, Haque, Little, \& Sinh, 2011). Instead, the overall quality assessment of fish is what determines the farmgate price.

\section{Data and descriptive statistics}

Our data have been obtained through qualitative interviews, a farmer survey, field observations, and published secondary material. The qualitative interviews included 52 informants with knowledge of the pangasius industry. The informants were selected using

\footnotetext{
${ }^{4}$ Khoi (2011) describes in detail how inputs change and production costs increase with the application of standards in pangasius production. That the approved inputs are more costly is also described elsewhere (see, e.g. Asfaw, Mithöfer, \& Waibel, 2010b).
} 
snowball sampling where the first interviewees came from research institutions and government offices. ${ }^{5}$ An overview of the interviewees and criteria used for selection are available in Table A1 in the Appendix. The support from local research institutions and the provincial Ministry of Agriculture and Rural Development (MARD) offices was crucial for reaching farmers and processing companies. All field visits were conducted in the presence of local researchers and MARD staff employed at province or commune level, which is necessary when doing field research in Vietnam, as noted in several studies (Belton, Little, et al., 2011; Scott, Miller, \& Lloyd, 2006). The interview format was semi-structured in most of the cases and based on open-ended questions. As dictated by the circumstances and respondents' preferences, two of the qualitative interviews were informal and 12 included information gathering through e-mail exchange. The interviews were led in English and in Vietnamese assisted by an interpreter when a respondent did not speak English. Only two interviews could be recorded and these were later transcribed. In all other cases we relied on note taking. The interview guide contained sections on organization and performance of the pangasius value chain, certification of standards and public regulation, production ownership and institutional framework. Trends and dynamics related to production, processing and export were also emphasized. The interviews lasted between 30 and 90 minutes depending on the respondent.

The farmer survey took place from April to June 2011 in three provinces in the MRD that have a high intensity of pangasius production: Can Tho, Dong Thap and An Giang. ${ }^{6}$ The survey included 276 pangasius farmers, however, as not all households wanted to reveal all wealth-related information our analysis includes only 270 households. We do not consider 6 out of 276 households (2\%) to be a serious non-response rate.

\footnotetext{
${ }^{5}$ The informants can be classified according to the following categories: input and service suppliers, farmers, processing companies, exporters, government representatives, and researchers. Informants were selected primarily based on their function in the value chain. Choosing the informants based on location was not highly relevant because several functions are performed outside or across the study provinces. For example, most of the service providers and exporters operate in all provinces in the Mekong River Delta, but their main offices are based in Ho Chi Minh City, the largest city in the area. When the interviews were performed in Ho Chi Minh City, it was made clear to the interviewees that the questions were aimed at obtaining the information about An Giang, Can Tho and Dong Thap provinces.

${ }^{6}$ These three provinces comprise $70 \%$ of total pangasius production in Vietnam (VASEP, 2012).
} 
The sampling of farmers for the survey was done in stages, as a complete list of pangasius farmers does not exist. The total number of pangasius farmers in Vietnam was estimated to be around 2,000 while the exact number for the three provinces included in the survey was unknown. ${ }^{7}$ The sampling started by a random selection of 25 communes from Dong Thap province. The aim was to collect data from all pangasius farmers in each of the 25 communes. In the second stage, at the commune level, we relied on commune staff to access farmers as the official lists of pangasius farmers did not exist. In total, we surveyed 197 farms in Dong Thap. Given the lack of official lists we cannot tell precisely if there were more than 197 pangasius farms in operation in the 25 communes in Dong Thap in 2010. Combining information from the 2006 Agricultural Census and local MARD offices the number of pangasius farmers in the selected communes was estimated to be 254 in 2010 so we may only have reached $78 \%$. But given the high fluctuation in the number of pangasius farmers (Belton, Little, et al., 2011), 254 farms may well be an upper bound rather than a precise number. Furthermore, as pangasius farmers are located in clusters and the commune staff differed by commune, we do not anticipate any systematic sample selection problems.

In An Giang we also selected communes randomly in the first stage, however, we were only able to visit 3 communes and interview 54 farmers. As in Dong Thap province, the aim was to sample all pangasius farmers in each commune and, again, we had no official lists of the total number of farms in the three communes or any reason to expect systematic sample selection problems at the commune level. Finally, to enlarge the sample in the econometric analysis we included farmers who were surveyed during the testing phase. Thus we also included 25 pangasius farms from two randomly selected communes in Can Tho.

\footnotetext{
${ }^{7}$ While the total number of pangasius farmers was estimated to be around 4,500 in 2009 (SFP, 2012), there were strong indications that this was not the case at the time of the survey. First, the general perception was that between 30 and 50\% of pangasius farmers had stopped producing since 2009 (Vietnamnews, 2011; Vina Seafood, 2009). Second, an interviewed industry expert estimated that the number of farmers was around 2,000 in 2011. Also, during the field visits, it was mentioned in all of the visited sites that the number of pangasius farmers had been declining.
} 
The total sample of 270 farms thus forms a random sample of the pangasius farmers in the MRD, but it is not possible to compute sampling weights to obtain results for the pangasius farm sector as such. As we look at the gain from adoption of food standards we do not consider this to be a major problem, but it must be borne in mind when considering the external validity of our analysis.

(a) Farm characteristics and benefits from standards

The questionnaire for the survey contain questions on key socio-economic indicators, particularly income and consumption expenditure; production inputs, assets and costs; marketing and support institutions; contract details; application of standards, and perceptions about the pangasius sector. The questions refer to the household situation in 2010. In the consumption expenditure module we cover the same questions as in the national Vietnam Household Living Standard Surveys (VHLSS), which are akin to the Living Standard Measurement Surveys (LSMS) questionnaires used by the Government of Vietnam and several research institutions for assessment of poverty and consumptionbased wellbeing in Vietnam. Details about the main variables we construct from the questionnaire are given in Table A2 in the Appendix.

Table 1 gives information about the prevalence of standards for the whole sample by ownership type and by province. In addition, we describe the farm size distribution and the adoption of standards within the size distribution. In our sample, 87 of the farms (32\%) are estate farms while the remaining 183 are traditional household-owned and operated farms. In relation to standards, it is interesting to note that a much larger fraction of the estate farms applies standards: $35 \%$ compared to only $20 \%$ of the household farms. This implies that almost half (46\%) of the farms applying standards are estate farms. It is equally interesting that also among the estate farms a large majority does not apply standards, such that they constitute $28 \%$ of the non-adopters. Thus, even though processors encourage application of standards to secure the Western export markets they own and invest in farms that produce fish that cannot be sold in these markets.

The size distribution of farms illustrates a highly skewed distribution with more than half of the farms having a small aquaculture area (less than 1 hectare) and about $20 \%$ of the 
farms being above 3 hectares. In terms of application of standards we note a significant difference between household-owned and estate farms in that the typical householdowned farm with standards is small while the typical estate farm with standards is large.

Table 1. Prevalence of standards among pangasius farms

\begin{tabular}{|c|c|c|c|c|c|c|c|c|c|}
\hline & \multirow{4}{*}{$\begin{array}{c}\text { Whole } \\
\text { sample } \\
\\
\text { (n) }\end{array}$} & \multicolumn{2}{|c|}{$\begin{array}{l}\text { Farms that } \\
\text { apply } \\
\text { standards }\end{array}$} & \multicolumn{3}{|c|}{$\begin{array}{l}\text { Distribution of farms by } \\
\text { size }\end{array}$} & \multicolumn{3}{|c|}{$\begin{array}{c}\text { Farms that apply } \\
\text { standards by farm size }\end{array}$} \\
\hline & & & & $<1$ & $1-3$ & $>3$ & $<1$ & $1-3$ & $>3$ \\
\hline & & & & ha & ha & ha & ha & ha & ha \\
\hline & & (n) & $(\%)$ & (n) & (n) & (n) & (n) & (n) & (n) \\
\hline Farm ownership & 270 & 68 & 25.19 & 154 & 60 & 55 & 31 & 17 & 20 \\
\hline Household-owned & 183 & 37 & 20.22 & 129 & 35 & 19 & 22 & 12 & 3 \\
\hline Estate farms & 87 & 31 & 35.63 & 25 & 25 & 36 & 9 & 5 & 17 \\
\hline
\end{tabular}

Table 2 presents averages of key household and farm characteristics, both for all farmers in the sample and by application of standards. When the difference between the two subsample averages is significantly different from zero (evaluated by standard $t$-test), we mark the mean for the group that applies standards by asterisks. The Table shows that 68 of the 270 farmers (25\%) apply standards. ${ }^{8}$ We do not distinguish between different standards, as the options are limited: Pangasius farmers could choose between GlobalGAP, BAP and SQF 1000 at the time of survey. ${ }^{9}$ Moreover, the distinction between various standards is not absolutely necessary because all of the mentioned standards focus on food safety and have similar requirements for farmers. The main reasons given for not adopting standards were lack of competences (20\%) and high costs (17\%). This observation is in line with other global value chains, notably the green bean

\footnotetext{
${ }^{8}$ Four farmers stated that they apply standards, but they were not certified so they were excluded from the analysis. Complying only with the EU, US or Vietnamese public regulation was not considered equal to complying with private standards for the purpose of this study. None of the farmers stated that they comply with more than one standard. As only four farmers are in the process of obtaining a certificate, it was not considered relevant for this study to explore differences between simple application and certification of standards.

${ }^{9}$ SQF 1000 is short for Safe Quality Food - a standard for primary producers developed by the Safe Quality Institute. All of the standards applied in the Vietnamese pangasius sector focus to some extent on the issues of water use and quality, biodiversity, feed quality, fish health and welfare, worker pay and conditions, worker health and safety, product quality and traceability (Belton, Haque, Little, \& Sinh, 2011). Among the surveyed farmers, $74 \%$ stated that they apply GlobalGAP. Therefore, we do not consider it important for this study to explore the effect of applying different types of standards.
} 
export sector in Kenya, where the number of smallholders has decreased due to their inability to finance compliance with food standards (Okello \& Swinton, 2007).

Table 2. Average household and farm characteristics and average differences between pangasius farms by application of food standards

\begin{tabular}{|c|c|c|c|c|c|}
\hline Variables & Measure & $\mathrm{N}$ & $\begin{array}{l}\text { Whole } \\
\text { sample }\end{array}$ & $\begin{array}{c}\text { No } \\
\text { standards }\end{array}$ & $\begin{array}{l}\text { Applying } \\
\text { standards }\end{array}$ \\
\hline Consumption expenditure, $p a e^{\mathrm{a}}$ & VND million & 270 & 6.48 & 6.30 & 6.99 \\
\hline Per capita yearly expenditure & VND million & 270 & 5.07 & 4.94 & 5.45 \\
\hline Yearly household expenditure & VND million & 270 & 17.87 & 17.25 & 19.69 \\
\hline Households in the sample & Number & 270 & 270 & 202 & 68 \\
\hline Household size & Persons & 270 & 3.74 & 3.72 & 3.78 \\
\hline Dependency ratio & Percent & 270 & 35 & 36.94 & 29.22 \\
\hline Age of the farm operator & Years & 270 & 42.29 & 42.30 & 42.28 \\
\hline Years of schooling & Years & 270 & 9.07 & 8.77 & $9.98^{* *}$ \\
\hline Farm size & Hectare & 270 & 3.14 & 2.94 & 3.73 \\
\hline Aquaculture area & Hectare & 269 & 2.64 & 2.32 & $3.57 * *$ \\
\hline Household labor & Persons & 270 & 2.11 & 2.16 & 2.09 \\
\hline Household labor share & Percent & 270 & 63.06 & 63.85 & 60.73 \\
\hline Off-farm employment & Percent & 270 & 30 & 32.17 & $20.59 * *$ \\
\hline Distance to buyer & Kilometer & 270 & 24.18 & 23.31 & 26.80 \\
\hline Own means of transport & Percent & 270 & 94.07 & 93.06 & 97.06 \\
\hline Estate farm & Percent & 270 & 32.22 & 27.72 & $45.59 * * *$ \\
\hline $\begin{array}{l}\text { Contract with a processing } \\
\text { company }\end{array}$ & Percent & 270 & 31.11 & 27.23 & $42.65 * * *$ \\
\hline
\end{tabular}

The first row in Table 2 reports our measure of wellbeing: consumption expenditure per adult equivalent. ${ }^{10}$ The average pangasius farmer is not poor by Vietnamese standards, but the consumption level is not far above the poverty line, when judged by the revised poverty line of 4.8 VND million applied for 2011 to 2015 (MOLISA, 2011). The median farm household is actually just about the poverty line for 2005-2010 and clearly below

\footnotetext{
${ }^{10}$ We use the OECD (2009) adult equivalent scale: 1 for the first adult, 0.7 for additional adults in the household and 0.5 for each child in the household.
} 
the revised poverty line for 2011-2015. ${ }^{11}$ Average consumption is slightly higher for farms applying standards but the difference in means is not statistically significant.

Table 2 shows that for typical household demographics such as household size, dependency ratio, and age of the farm operator we find a reasonable agreement with average household characteristics, as given in the 2010 VHLSS (GSO, 2011) and there are no differences in these characteristics across farms applying and not applying standards. ${ }^{12}$ It is therefore noteworthy that the educational level of the farm operator differs significantly between adopters and non-adopters of standards. The average farm operator who adopts standards has more than one extra year of schooling compared to the average non-adopter.

The average total farm size is just above 3 hectares, with a somewhat larger average size for the farms that apply standards, although the difference is not statistically significant. The area used for aquaculture is, however, significantly larger for the farms who apply standards and, being more than 1 hectare, the average difference is also economically substantial. Despite the larger average farm size the households applying standards do not use more household labor on the farm, as both farm types employ just above two workers from the household, on average, which gives an average household labor share just above $60 \%$. Even so, a significantly smaller share of the farms that apply standards has off-farm employment compared to the non-adopters (about one-in-five of the adopter farms compared to one-in-three for the non-adopters).

In terms of location, we also find only minor differences between adopters and nonadopters of standards. The average distance to the buyer is just below $25 \mathrm{~km}$ for the nonadopters while it is just above that for the adopters. However, the difference is statistically insignificant. Another measure of relative isolation (and wealth) is whether

\footnotetext{
${ }^{11}$ The National poverty line (given by the Ministry of Labor, Invalids and Social Affairs, MOLISA) is income based, but it is close to the consumption-based measure given by the General Statistical Office (GSO). The MOLISA poverty line was 2.4 million VND per capita for 2005-2010 while it has been adjusted to 4.8 million VND per capita for 2011-2015.

${ }^{12}$ The average household size in Dong Thap and Can Tho was 3.9 while it was 4.2 in An Giang in 2010 according to the VHLSS 2010 (GSO, 2011).
} 
the farm household owns a means of transportation. In the MRD, the main means of transportation are either a boat or a motorcycle, depending on the location. As seen from Table 2, almost all households in the sample have at least one of these. This, however, does not imply that the farmers bring the fish to the buyers themselves.

Another characteristic in which we find substantial differences between the two farm types is in relation to contractual agreements with processors. Just below half (42\%) of the farms applying standards have contracts with processing companies, while this is only the case for about one-fourth (27\%) of the farms not applying standards. This difference is important because standards are generally used to overcome information asymmetries in food quality and as such, we would expect contracts to be less needed, and thus less frequent, among farmers applying standards. However, production contracts cover more than fish quality and, as we show later, the largest gain in terms of farmgate price is given to farms that have both standards and contracts.

Irrespective of ownership structure we see the highest prevalence of standards in the $75 \%$ quantile of the expenditure distribution (Table 3). The occurrence of standards is significantly higher in this quantile compared to all other quantiles, except at the median.

Table 3. Prevalence of standards among pangasius farms by expenditure quantile

\begin{tabular}{lcccccc}
\hline & \multicolumn{7}{c}{ Quantile (\%) } \\
\cline { 2 - 7 } & 0.15 & 0.25 & 0.50 & 0.75 & 0.85 & 0.95 \\
\hline Standards & 2.59 & 2.54 & 5.43 & 7.41 & 1.81 & 2.90 \\
Non-standards & 13.41 & 7.25 & 19.57 & 17.39 & 7.97 & 7.25 \\
\hline & & & \multicolumn{5}{c}{ Source: Farmer survey. }
\end{tabular}




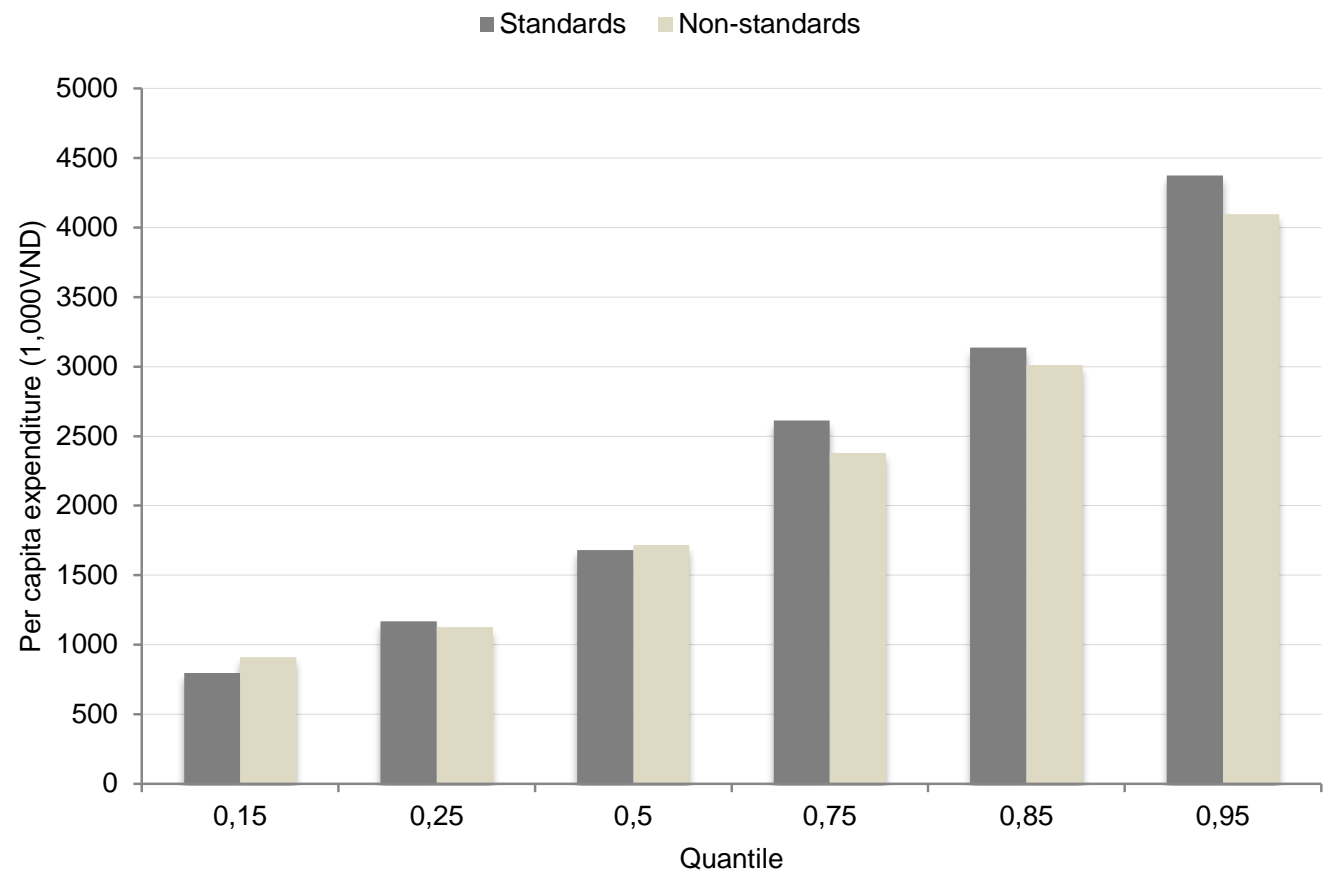

Figure 2. Differences in the expenditure level between adopters and non-adopters of standards by quantile

Source: Farmer survey.

Although there is no difference in the average consumption levels, we show in Figure 2 that there are distributional differences between adopters and non-adopters of standards. Indeed, the quantile-level differences in favor of farms with standards are especially visible for quantiles above the median, where the households who apply standards have on average $7 \%$ higher consumption expenditure levels.

\section{Econometric analysis of welfare effects}

The descriptive analysis illustrates that the average levels of consumption expenditure for adopters and non-adopters of standards are very similar, while there may be small differences between consumption levels for households in the upper quantiles of the expenditure distribution. Clearly, this does not imply that standards have no impact on expenditures or that it only affects expenditures for the better-off pangasius farmers. Therefore, we test econometrically the impact of applying standards on consumption 
expenditure. As illustrated in Tables 1 and 2, farms applying standards are not randomly distributed in the sample (or the population): The prevalence of standards is higher for estate farms than household-owned farms, for farms with production contracts and it is positively associated with the education of the farm operator.

\section{(a) Econometric specification}

A common approach to impact evaluation based on cross-section data like ours is to assume independence of the outcome and the treatment conditional on observables. ${ }^{13}$ This assumption leads to impact estimation using either standard (OLS) regression or matching (see, e.g. Imbens \& Wooldridge, 2009). The list of observable covariates is hard to specify precisely, in particular in our setting in which we seek to estimate the impact on consumption expenditure, but most of the variables given in Table 2 are common controls in expenditure models. Thus, apart from aquaculture area, which is endogenous as application of standards requires changes in the pond size, we will control for the variables given in Table 2.

To estimate the impact of applying standards on the wellbeing of pangasius farmers, we formulate a simple reduced form model for consumption expenditure in which expenditure depends on farm characteristics. Even though the list of observed characteristics is extensive, the decision to adopt standards is inherently based on unobservable farm and farmer characteristics including the specific location relative to the river, managerial skills, and social network ties with other farmers and processors. Hence, in order to reduce bias while estimating the causal effect of standards, we will also apply instrumental variable regression, which can be formulated as a two-equation model with a selection equation determining if a farmer is applying standards and an outcome equation describing consumption expenditure. Specifically, we may formulate this as:

$$
\begin{gathered}
S_{i}=\pi_{0}+\pi_{1} Z_{i}+\gamma X_{i}+\eta_{i} \\
Y_{i}=\alpha+\delta S_{i}+\beta X_{i}+\varepsilon_{i}
\end{gathered}
$$

\footnotetext{
${ }^{13}$ Maertens and Swinnen (2009) is a relevant example.
} 
where per capita consumption expenditure in household $i$ is denoted $Y_{i}$. The observable farm characteristics are gathered in the vector $X_{i}$ while the unobserved farm characteristics are gathered in $\varepsilon_{i}$. The impact of adoption of food standards is included in the model by the indicator variable $S_{i}$, taking the value 1 if household $i$ applies standards and 0 of the household has traditional production. Being endogenous, application of standards is determined in the selection equation (1) in which we introduce instrumental variables, $Z_{i}$, for individual household adoption of food standards.

Finding admissible and relevant instruments for income generating decisions in consumption models is not easy. In previous studies Asfaw et al. (2010b) used the predicted probability of adoption of EurepGAP standard as an instrument for food standard adoption, while Bolwig et al. (2009) used the ratio of non-farm income to total revenue in an impact evaluation of organic certification. The admissibility of both of these instruments can be debated, which is why we take a different route.

Based on insights from the technology adoption literature we think of network and information variables as good candidates for valid and relevant instruments. ${ }^{14}$ However, measuring knowledge and information is notoriously difficult so we revert to two crude indicators of knowledge. As one measure, we generate a village level indicator variable that takes the value 1 if at least one farm in the village applies standards. By this, we assume that specific production knowledge spreads more easily within villages (friends and neighbors) than across villages. Further, by restricting the instrument to village level information we seek to avoid, or at least reduce, the correlation with unobservable individual farmer characteristics such as managerial skills.

Our second measure is more direct as we use the information about the individual farmer's knowledge about standards from the farmer survey. This instrumental variable

\footnotetext{
${ }^{14}$ The importance of networks and the efficiency of information flows in the process of new technology adoption is emphasized in several studies spanning across different countries (Boahene, Snijders, \& Folmer, 1999; Conley \& Udry, 2010; Matuschke \& Qaim, 2009), as well as the livelihood and market access literature (Bacon, 2005; Blanc \& Kledal, 2012; Suzuki, Jarvis, \& Sexton, 2011).
} 
takes value 1 if a farmer has ever heard about standards and 0 otherwise. Table 4 shows the information we obtained from the survey when we asked about the sources of information about food standards. The most frequently mentioned sources are extension officers and mass media such as newspapers and TV. Information spread through these media is very common in Vietnam. Friends, neighbors and relatives are also frequent sources of information, while buyers are rarely mentioned.

Table 4. Main sources of information about standards

\begin{tabular}{lcc}
\hline Source & Number & Percent \\
\hline Magazines/Newspapers/Books & 91 & 33.70 \\
Friends/Neighbors/Relatives & 56 & 20.74 \\
NGOs & 1 & 0.37 \\
Internet & 33 & 12.22 \\
TV & 91 & 33.70 \\
Radio & 9 & 3.33 \\
Government institutions & 11 & 4.07 \\
Community leader & 23 & 8.52 \\
Extension officers & 126 & 46.67 \\
Buyers & 14 & 5.19 \\
\hline Note: N = 192; multiple options are possible. Source: Farmer survey & &
\end{tabular}

In Table 5 we show the associations between application of standards and the two knowledge variables. It is clear that no farmers are applying standards without knowing about standards, thus there are no instances in which the knowledge variable takes the value 0 (no knowledge) when the standards indicator variable takes the value 1 (the farmer applies a standard). But there are many farmers who have heard about standards, but do not apply the standards (124 farmers) and also many who have not heard about and do not apply standards (78 farmers). The distribution of the village-level knowledge of standards (emphasizing more specific knowledge) is different as there are fewer farmers living in villages in which at least one farmer applies standards that do not apply standards themselves (94) compared to the ones who apply (108). 
Table 5. Associations between standards and the information about standards

\begin{tabular}{|c|c|c|c|c|}
\hline \multirow[b]{2}{*}{$\begin{array}{l}\text { Knowledge } \\
\text { variable }\end{array}$} & \multicolumn{2}{|c|}{$\begin{array}{l}\text { Not applying standards } \\
(0)\end{array}$} & \multicolumn{2}{|c|}{$\begin{array}{l}\text { Applying standards } \\
\text { (1) }\end{array}$} \\
\hline & $\begin{array}{c}\text { IV1 } \\
\text { Village-level } \\
\text { standards }\end{array}$ & $\begin{array}{c}\text { IV2 } \\
\text { Heard about } \\
\text { standards }\end{array}$ & $\begin{array}{c}\text { IV1 } \\
\text { Village-level } \\
\text { standards }\end{array}$ & $\begin{array}{c}\text { IV2 } \\
\text { Heard about } \\
\text { standards }\end{array}$ \\
\hline No $(0)$ & 94 & 78 & 0 & 0 \\
\hline Yes (1) & 108 & 124 & 68 & 68 \\
\hline
\end{tabular}

Note: The Pearson $\chi^{2}(1)$ test of independence between applying standards and IV1 (village-level application of standards) is $48.54(p<0.0001)$. The value of the Pearson $\chi^{2}(1)$ test of independence between applying standards and IV2 (heard about standards) is $36.92(p<0.0001)$. Source: Farmer survey.

Ideally, the knowledge of standards should be randomly distributed across the pangasius farmers in the region. In that case this information could be used to obtain the intent to treat effect of standards. However, the distributions are not independent of farm characteristics but we assume they are conditionally independent of consumption expenditure. This means that we both expect and allow for knowledge to depend on observable farm and farmer characteristics such as education, location (province and distance to buyer) and other observables, but we expect knowledge to be randomly distributed among farmers with equal characteristics, and we further assume that this information has no independent impact on consumption expenditure. These assumptions are the basis for using the knowledge variables as instruments in our impact assessment. Using the instruments in 2SLS regressions, our impact estimator corresponds to a Local Average Treatment Effect (LATE). ${ }^{15}$ The LATE is the effect of treatment for those whose treatment status is changed by the instrument(s), termed the compliers in Angrist et al. (1996).

As the main objective of our study is to show that the impact of standards is not uniform across the expenditure distribution, we expand the instrumental variable regression model to quantiles of the expenditure distribution. Specifically, we estimate quantile regressions in which expenditure is conditional on the covariates, $X_{i}$, and we use the knowledge variables as instrument(s) for individual household food standard adoption: ${ }^{16}$

\footnotetext{
${ }^{15}$ Imbens and Angrist (1994) and also Abadie et al. (2002) state that if the key IV assumptions are fulfilled, any observed relationship between the treatment and the outcome has a causal interpretation for compliers.

${ }^{16}$ We use the STATA ivqte routine developed by Frölich and Melly (2010).
} 


$$
Q_{\theta}\left(Y_{i} \mid X_{i}, Z_{i}\right)=\alpha_{\theta}+\delta_{\theta} S_{i}+\beta_{\theta} X_{i}
$$

where $Q_{\theta}\left(Y_{i} \mid X_{i}, Z_{i}\right)$ denotes the $\theta$-quantile of $Y_{i}$ given $X_{i}$, and $S_{i}$ for compliers. The instrumental variable quantile regressions require linearity of the consumption model and a set of more technical assumptions given in Abadie et al. (2002). Given linearity, the assmptions are, however, only slightly more restrictive than the usual assumptions in propensity score matching.

(b) Econometric results

The results for the average impact of food standards on farmers' wellbeing are presented in Table 6, while the quantile impact estimates are given in Table 7. The complete sets of estimated parameters for the regressions in Table 6 are given in Tables A3, A4 and A5 in the Appendix.

Table 6. Average impact of standards on consumption expenditure

\begin{tabular}{lcccc}
\hline Estimator & OLS & 2SLS IV1 & 2SLS IV2 & 2SLS IV1 and IV2 \\
\hline Full sample & $0.180^{*}$ & $0.443^{*}$ & $0.696^{*}$ & $0.558^{* *}$ \\
& $(0.104)$ & $(0.257)$ & $(0.420)$ & $(0.241)$ \\
Farms smaller than $1.2 \mathrm{ha}^{\mathrm{a}}$ & -0.199 & 0.381 & -0.197 & 0.093 \\
& $(0.156)$ & $(0.441)$ & $(0.620)$ & $(0.422)$ \\
Farms larger than 1.2 ha & $0.490^{* *}$ & 0.452 & $1.530^{* * *}$ & $0.838^{* * *}$ \\
& $(0.195)$ & $(0.327)$ & $(0.462)$ & $(0.259)$ \\
\hline
\end{tabular}

Note: IV1: village-level standards; IV2: heard about standards. Full regression results are given in Tables A3, A4 and A5. The full sample results have 270 observations; the split sample results each have 135 observations. ${ }^{\text {a }}$ The median farm size in the sample is 1.2 hectares. Robust bootstrapped standard errors clustered at the commune level in parentheses; ${ }^{*} \mathrm{p}<0.10,{ }^{* *} \mathrm{p}<0.05$, ${ }^{* * *} \mathrm{p}<0.01$. Source: Farmer survey.

The first result in Table 6 is that when conditioning on observables, the estimated average impact of standards is an increase in per capita consumption just below 20\%. The effect is not precisely determined and it is only marginally significant at the 10 percent level. Accounting for the possible endogeneity of food standard adoption, the three 2SLS regressions yield average impact estimates from 0.443, corresponding to an increase in consumption of 56\% (using the instrument that at least one farm in the village is applying standards) to 0.696 corresponding to an increase in consumption of $100 \%$ (using the 
instrument that the farmer has heard about standards). Including both instruments results in an estimate in between the two. Thus the 2SLS regressions show impacts that are more than twice the size of the corresponding OLS coefficient. This result is stable across all our model formulations, which is why we discuss it in more detail in the next section.

As a first illustration of the heterogeneous impacts of standards on consumption expenditure we split the sample of farmers according to farm size. To avoid specification searches we simply split the sample in half, and this corresponds to a sample of 135 farmers with farm sizes less than 1.2 hectares and 135 famers with farm sizes of at least 1.2 hectares. The average impact estimates are given in Table 6 below the full sample estimates. For the small farms, we obtain a negative point estimate in the OLS regression and in one of the 2SLS regressions, but the estimates are statistically insignificant throughout. Thus we find no impact of standards on small farms. In contrast, the impact is substantial and statistically significant for the sub-sample of large farms. This is interesting in light of the distribution of application of standards across ownership and farm size in Table 1. The results indicate that small, household-owned farms do not gain from applying standards.

The first stage regression estimates in Table A4 in the Appendix show that the weak instrument hypothesis is easily rejected in all three 2SLS regressions as the F-statistic values surpass the critical values given in Stock and Yogo (2005). Also, we show in Table A3 that Hansen $J$-test for overidentification when both instruments are used in the estimation does not lead us to reject the hypothesis of valid instruments.

In Table 7 we assess the distributional differences in the impact of standards in a more systematic way by estimating the local average impact at the $15 \%, 25 \%, 50 \%, 75 \%, 85 \%$ and $95 \%$ quantiles of the expenditure distribution. The specification of the quantile regressions is exactly as the least squares and 2SLS regressions in Table 6. We report results of both standard quantile regressions, corresponding to the OLS results in Table 6, and instrumental variable quantile regressions, corresponding to the two first 2SLS regressions in Table 6. 
Table 7. Local average impact at different quantiles of the expenditure distribution

\begin{tabular}{lcccccc}
\hline & \multicolumn{5}{c}{ Quantile (\%) } \\
& 15 & 25 & 50 & 75 & 85 & 95 \\
\hline QR & 0.215 & $0.254^{*}$ & 0.106 & 0.085 & 0.089 & -0.073 \\
& $(0.159)$ & $(0.142)$ & $(0.126)$ & $(0.194)$ & $(0.225)$ & $(0.342)$ \\
IVQR1 & 0.086 & 0.275 & $0.786^{* * *}$ & $0.805^{* *}$ & $0.890^{* *}$ & 0.495 \\
& $(0.246)$ & $(0.208)$ & $(0.220)$ & $(0.349)$ & $(0.348)$ & $(0.409)$ \\
IVQR2 & 0.158 & 0.219 & $0.483^{* *}$ & $0.507^{*}$ & 0.034 & 0.036 \\
& $(0.266)$ & $(0.197)$ & $(0.216)$ & $(0.259)$ & $(0.401)$ & $(0.586)$ \\
IV1 validity (t-value) & 0.71 & 1.07 & 0.95 & 0.59 & 1.21 & 0.12 \\
IV2 validity (t-value) & 1.24 & 0.71 & 1.49 & $2.04^{* *}$ & 1.20 & 0.09 \\
\hline
\end{tabular}

Note: QR: quantile regression; IVQR1: instrumental variable quantile regression with IV1 (village-level application of standards); IVQR2: instrumental variable quantile regression with IV2 (heard about standards). The control variables are the same as in Table 6 . Validity of instrumental variables was assessed using a Sargan-type regression where the instrumental variables are used as controls. Robust bootstrapped standard errors clustered at the commune level in parentheses; ${ }^{*} \mathrm{p}<0.10,{ }^{* *} \mathrm{p}<0.05,{ }^{* * *} \mathrm{p}<0.01$. Source: Farmer survey.

The standard quantile regressions show small and statistically insignificant effects of standards on consumption expenditure, apart from a marginally significant impact at the $25 \%$ quantile. The point estimates are largest for the poorer households and they decline somewhat as we move towards the richest households. The instrumental variable results are quite different as the estimated impact is both large and statistically significant for the upper middle class defined as the $50-85 \%$ quantiles of the consumption expenditure distribution. The two instruments give quantitatively different results, as expected, but the profiles of the impact across the expenditure distribution are similar: The local effect is large (and significant) at the median and the upper quantile while it is low (and insignificant) below the median and at the upper tail of the distribution. Overall, Table 7 indicates that the gain from standards is an increase in consumption expenditure of about $60 \%$ or more for the upper middle class while there is no gain for the poorest. This result finds support in the estimation on the sample split by the median farm size in Table 6.

In Table 7 we also show results for a test of validity of instrumental variables using a Sargan-type regression where the instrumental variables are included as controls 
alongside the other controls and the (endogenous) indicator of application of standards. The t-test of the instrument is the Sargan-type test of validity. The test does not lead us to suspect an individual (direct) effect of the instruments on consumption expenditure although the second instrument has a marginally significant effect on consumption at the 75\% quantile. However, given the number of individual tests this is not unexpected and we do not think of this as strong evidence against the validity of our instruments.

\section{Discussion}

The estimated impacts of food standards are substantial - for the upper middle-class. Consumption expenditure increases of $60-140 \%$ appear excessive and one may also ask why the local average impact is smaller, and insignificant, for the wealthiest farmers.

Clearly, if standards are to increase income and consumption they must either increase the revenue or reduce costs of production. For pangasius, standards signal both superior product quality and reduced quality uncertainty. The most obvious gain from application of standards is therefore higher farm-gate prices. In Figure 3 we show the distribution of farmgate prices for 172 farmers who have reported this price (128 of these farmers did not apply standards while the remaining 44 did). The interesting observations with regard to the farmgate prices are that the prices vary substantially (by a factor of 3) and that the ranges of prices for pangasius produced traditionally and under standards are almost equal. Thus, although the average farmgate price is $11 \%(2,130 \mathrm{VND} / \mathrm{kg})$ higher when producing under standards, there are many farmers with traditional production who receive a high price. The higher price in standard-led production is most likely a consequence of better quality. 


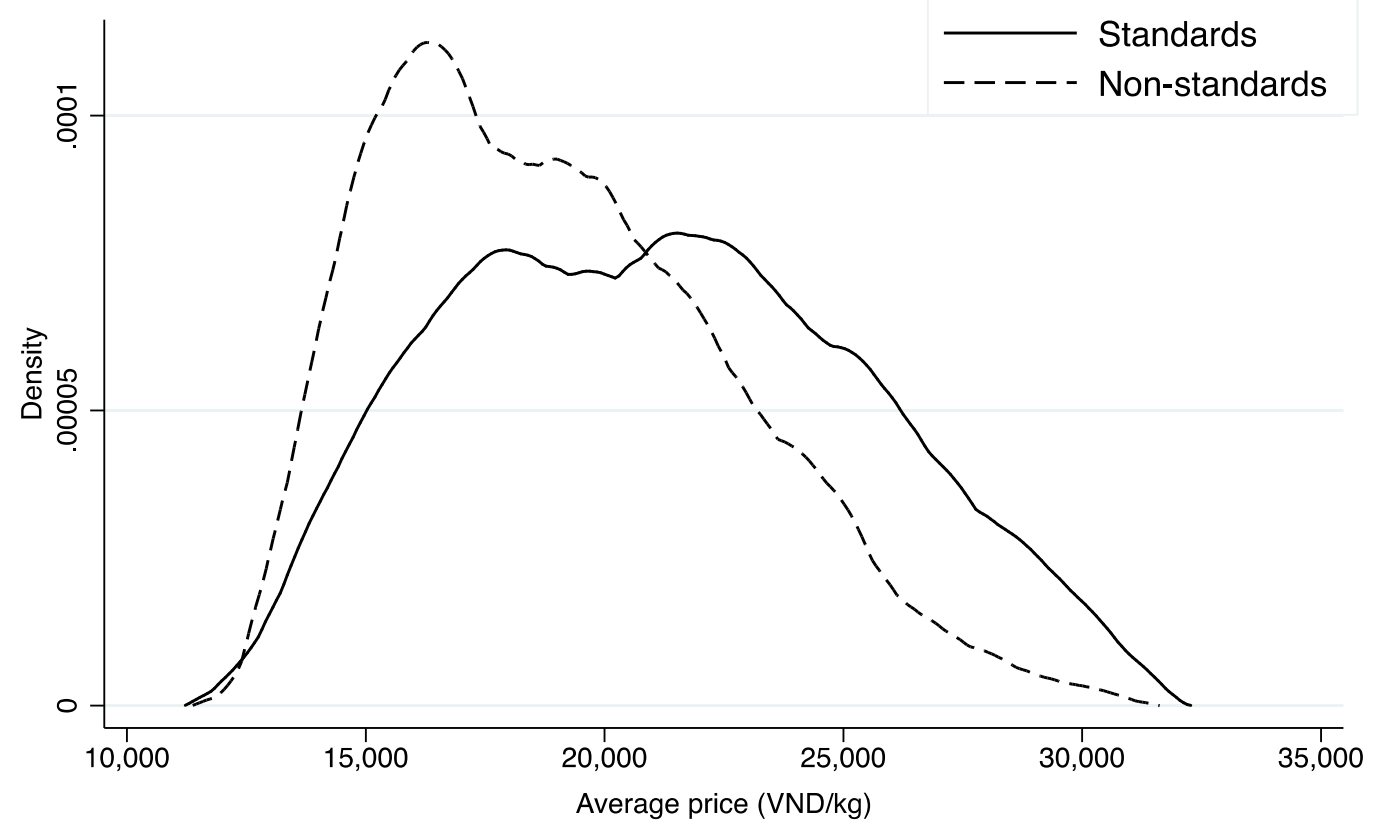

Figure 3. Distribution of farm-gate prices for farms with and without standards

Source: Farmer survey.

In Table 8 we report group means, standard deviations, minimum and maximum for the farmgate prices by application of standards, ownership, and contractual arrangement with processors. The highest average price is given to household farmers with both a contract and standards, while the second highest price is given to estate farms with both a contract and standards. Hence, there is little doubt that food standards are associated with higher prices. However, ownership and contractual arrangements blur the simple relationship because estate farms actually obtain high prices, on average, also without standards and even without contracts. Moreover, the household farms producing under standards but without a contract actually get a fairly low price, on average, which is comparable to the average prices obtained for households that do not apply standards. Furthermore, while the household-owned farms that do not apply standards have the lowest average price, the price range is wide and the highest prices given to these farmers are actually above the highest prices given to farms that apply standards, but do not have contractual arrangement with processors. Thus, a switch from traditional production to applying standards is unlikely to be associated with a higher farmgate price for many households, in particular if the household farm does not also have a contract. 
Table 8. Summary statistics for the farmgate prices by standards, ownership and contractual arrangement

\begin{tabular}{cccccccc}
\hline Standards & Ownership & Contract & N & Average price & s & Min & Max \\
\hline No & Household & No & 46 & 18,260 & 3,455 & 14,000 & 29,000 \\
No & Household & Yes & 41 & 18,857 & 3,469 & 14,650 & 27,000 \\
No & Estate & No & 21 & 20,067 & 3,771 & 14,700 & 28,500 \\
No & Estate & Yes & 20 & 20,190 & 3,007 & 14,500 & 26,500 \\
Yes & Estate & No & 4 & 19,875 & 3,400 & 16,500 & 24,500 \\
Yes & Estate & Yes & 15 & 21,380 & 4,096 & 15,000 & 28,500 \\
Yes & Household & No & 11 & 18,641 & 2,930 & 15,500 & 24,000 \\
Yes & Household & Yes & 14 & 23,386 & 4,044 & 16,500 & 28,400 \\
\hline & & & & & & Source: Farmer survey
\end{tabular}

This may explain why the selection bias is negative, leading to larger impact estimates in the IV-regressions compared to just conditioning on observables. Skilled, or wellconnected farmers may not apply standards because they do not need to, as they already produce high quality fish and obtain high prices. In this case, adoption of standards is negatively correlated with the error term in the regressions because it is, conditionally, the relatively less capable farmers who apply standards, thereby signaling high quality to the processors. It also explains why the wealthiest farmers do not apply standards, if these are also the most capable farmers. To reaffirm this, we show in Table A6 in the Appendix that farmers in the top quantile of the expenditure distribution are more prone to consider standards as impractical compared to farmers in other quantiles. In addition, farmers in the top quantile appear to be more cost sensitive than farmers in other quantiles as the main reasons for not adopting standards in this quantile were high costs for establishment upgrade, consultancy and certification. Using the instrumental variables based on knowledge and information, we estimate the local average effect of switching to standards for farmers with (conditionally) average capabilities and for these farmers, the gains are evidently large.

To supplement the regression-based results, we add information on the motivation of farmers to start applying standards across quantiles. Table A7 in the Appendix tells that the farmers who apply standards in the top quantile are, just as the farmers in other 
quantiles, motivated to apply standards in order to improve market reach and obtain higher product price. All groups of farmers stated that the main reason for applying standards is to improve product quality. Still, farmers in the top quantile are the only group stating that they do not expect to reduce the occurrence of fish diseases with the application of standards. This reaffirms our point that these farmers are probably better able to manage production of pangasius. However, there is an upper bound to which the increase in quality is reflected in price and the application of standards ceases to have effect. Indeed, farmers who apply standards in the top quantile do not receive much higher price compared to the non-applicants $(t=0.91)$, which may additionally explain why the gain from standards is not significant in this quantile.

For the poorer farmers, the small and insignificant impact of standards on consumption expenditure must have another explanation. Lacking information about investment costs we can only speculate about the underlying cause, but one reason could be that poorer farmers may have difficulty in inferring returns from the new technology (Munshi, 2004), or they may face specific constraints, such as restrictions in the capital market, which prevent adoption. In a study on the adoption of a new hybrid maize variety, Suri (2011) finds that farmers with the highest estimated gross returns do not use the new variety. Instead, their returns are correlated with high costs of acquiring the technology due to supply constraints associated with poor infrastructure. The farmers in our sample have most frequently stated that too high costs of implementation (41\% of non-applicants) and lack of competences (37\% of non-applicants) are the key inhibiting factors for the implementation of standards. This lends support to both explanations.

Even though we have both a different outcome measure and use different estimation methods, our results seem comparable to Asfaw et al. (2010b) who find an increase in net production revenue of around $60 \%$ for Kenyan farmers that have adopted the EurepGAP standard. Our results are also comparable to impact estimates in Maertens and Swinnen (2009) showing 60-110\% increases in income from participation in French bean export production. But, direct comparisons of the size of the estimated impact of food standards on farmers' wellbeing in this paper with the size of the impact in other papers are not 
straightforward. First, our 2SLS results determine local average treatment effects, which are sensitive to the choice of instrument, as we illustrate. But, the instrument itself does not always highlight which subset of the population it affects (Heckman, 1997), so it is usually not possible to know who is induced to adopt standards by an instrument. In addition, the two comparable studies, using propensity scores (Maertens \& Swinnen, 2009) and exclusion restrictions (Asfaw et al., 2010b) are most likely also estimating a local average treatment effect (LATE) instead of the average treatment effect (ATE). Second, previous studies have measured the impact of standards on household income (Maertens \& Swinnen, 2009) and net income from export vegetables (Asfaw et al., 2010b). We, however, focus on consumption expenditure because i) imprecisions in inferring the true income level often arise from the inability to measure all types of costs borne by the households, especially differing investment costs and loan interest rates; and ii) comparing household-owned and estate farms in terms of income is not reasonable because companies, not estate farm employees invest on these farms. Comparing the income levels would then overestimate the welfare effect of food standards on the estate farms.

\section{Conclusion}

Using cross-sectional farm household data collected in the Vietnamese pangasius sector in 2011, we estimate the impact of food standards on farmers' wellbeing, measured by consumption expenditure per adult equivalent. The impact of standards is estimated at the mean and at selected quantile levels. Because the adoption of food standards is partly determined by farm specific unobservable factors that also influence consumption we use instrumental variable regressions to estimate the causal effect of food standard adoption.

Our results show that the additional effort in terms of modified production practices and use of improved inputs pays off for the applicants of standards as we find a positive overall impact of standards on farmers' wellbeing. Thus, on average, one should expect pangasius farms that apply standards to be better off than comparable farms with

traditional production. This suggests not only that investment in food standards is necessary in modern value chains, but also that this investment can lead to subsequent 
financial gains. However, the impact of standards on farmers' wellbeing is heterogeneous. We find that only households at higher levels in the expenditure distribution who have opted for the application of food standards get significant benefits.

While we expected to find a homogeneous positive effect of standards for richer farmers, i.e. the farmers beyond the median consumption level, our findings surprisingly show that the wealthiest farmers (top 15\%) do not gain from standards. This finding illustrates that standards are not as useful to the wealthiest farmers with an established market position as to the middle-class farmers. Clearly, the specificities of cultural and business environment are successfully employed by the richest farmers to circumvent the requirements for standards.

Our impact estimates do not include indirect distributional effects such as general equilibrium effects via the labor market. Therefore, while we can only infer that standards are directly beneficial for the upper middle-class, we cannot conclude that the poorest farms are, or will be, marginalized. Further, our analysis does not allow a finetuned evaluation of the kinds of interpersonal and business relationships that can be especially conducive to participating in high-value export sector and benefiting from standards. Such analysis could potentially include surveying farmers, processing companies and exporters. Further research comprising repeated surveys would be needed to look into long-term effects of standard adoption among small-scale farmers.

Still, our results bear significance for development policies because they indicate that standards can be a strategic tool in rural sector development, but care needs to be directed towards small-scale farmers, probably through financial and technical assistance. In case of the Vietnamese pangasius farmers, better credit options and training are most likely desirable, together with organizational and business development. Group certification of small farmers has been a solution to high cost of certification in other countries but such an option needs to be evaluated against cultural, social, and political conditions in Vietnam. 


\section{References}

Abadie, A., Angrist, J. D., \& Imbens, G. W. (2002). Instrumental Variables Estimates of the Effect of Subsidized Training on the Quantiles of Trainee Earnings. Econometrica, 70(1), 91-117.

Asfaw, S., Mithöfer, D., \& Waibel, H. (2010a). Agrifood supply chain, private-sector standards, and farmers’ health: evidence from Kenya. Agricultural Economics, 41(3-4), 251-263.

Asfaw, S., Mithöfer, D., \& Waibel, H. (2010b). What Impact Are EU Supermarket Standards Having on Developing Countries’ Export of High-Value Horticultural Products? Evidence From Kenya. Journal of International Food \& Agribusiness Marketing, 22(3-4), 252-276.

Bacon, C. (2005). Confronting the Coffee Crisis: Can Fair Trade, Organic, and Specialty Coffees Reduce Small-Scale Farmer Vulnerability in Northern Nicaragua? World Development, 33(3), 497-511.

Belton, B., Haque, M. M., Little, D. C., \& Sinh, L. X. (2011). Certifying catfish in Vietnam and Bangladesh: Who will make the grade and will it matter? Food Policy, 36(2), 289-299.

Belton, B., Little, D. C., \& Sinh, L. X. (2011). The social relations of catfish production in Vietnam. Geoforum, 42(5), 567-577.

Blanc, J., \& Kledal, P. R. (2012). The Brazilian organic food sector: Prospects and constraints of facilitating the inclusion of smallholders. Journal of Rural Studies, 28(1), 142-154. doi:10.1016/j.jrurstud.2011.10.005

Boahene, K., Snijders, T. A. ., \& Folmer, H. (1999). An Integrated Socioeconomic Analysis of Innovation Adoption: The Case of Hybrid Cocoa in Ghana. Journal of Policy Modeling, 21(2), 167-184. doi:10.1016/S0161-8938(97)00070-7

Bolwig, S., Gibbon, P., \& Jones, S. (2009). The Economics of Smallholder Organic Contract Farming in Tropical Africa. World Development, 37(6), 1094-1104.

Bush, S. R., \& Duijf, M. (2011). Searching for (un)sustainabilty in pangasius aquaculture: A political economy of quality in European retail. Geoforum, 42(2), 185-196.

Colen, L., Maertens, M., \& Swinnen, J. F. M. (2012). Private Standards, Trade and Poverty: GlobalGAP and Horticultural Employment in Senegal. The World 
Economy, 35(8), 1073-1088.

Conley, T. G., \& Udry, C. R. (2010). Learning about a New Technology: Pineapple in Ghana. American Economic Review, 100(1), 35-69.

FAO. (2010). FAO GLOBEFISH - Pangasius - March 2010. Food and Agriculture Organisation of United Nations. Retrieved March 18, 2012, from http://www.globefish.org/pangasius-march-2010.html

FAO. (2012). Global Aquaculture Production 1950-2010. FIGIS - Fisheries Statistics Aquaculture. Food and Agriculture Organisation of United Nations. Retrieved March 18, 2012, from http://www.fao.org/fishery/statistics/global-aquacultureproduction/query/en

Farina, E. M. M. Q., \& Reardon, T. (2000). Agrifood Grades and Standards in the Extended Mercosur: Their Role in the Changing Agrifood System. American Journal of Agricultural Economics, 82(5), 1170 -1176. doi:10.1111/00029092.00116

Foster, A. D., \& Rosenzweig, M. R. (1995). Learning by Doing and Learning from Others: Human Capital and Technical Change in Agriculture. Journal of Political Economy, 103(6), 1176-1209.

Frölich, M., \& Melly, B. (2010). Unconditional Quantile Treatment Effects under Endogeneity. The Stata Journal, 10(3), 423-457.

GAA. (2011). BAP Standards. The Global Aquaculture Alliance. Retrieved March 18, 2012, from http://www.gaalliance.org/bap/standards.php

Galiani, S., \& McEwan, P. J. (2013). The heterogeneous impact of conditional cash transfers. Journal of Public Economics, 103, 85-96. doi:10.1016/j.jpubeco.2013.04.004

Giovannucci, D., \& Ponte, S. (2005). Standards as a new form of social contract? Sustainability initiatives in the coffee industry. Food Policy, 30(3), 284-301. doi:10.1016/j.foodpol.2005.05.007

GSO. (2011). Statistical Yearbook of Vietnam 2010. Hanoi: General Statistics Office Of Vietnam.

Heckman, J. J. (1997). Instrumental Variables: A Study of Implicit Behavioral Assumptions Used in Making Program Evaluations. Journal of Human Resources, 
32(3), 441-462.

Henson, S., \& Humphrey, J. (2010). Understanding the Complexities of Private Standards in Global Agri-Food Chains as They Impact Developing Countries. Journal of Development Studies, 46(9), 1628-1646.

Henson, S., \& Jaffee, S. (2008). Understanding Developing Country Strategic Responses to the Enhancement of Food Safety Standards. The World Economy, 31(4), 548568.

Henson, S., Masakure, O., \& Cranfield, J. (2011). Do Fresh Produce Exporters in SubSaharan Africa Benefit from GlobalGAP Certification? World Development, 39(3), 375-386. doi:10.1016/j.worlddev.2010.06.012

Henson, S., \& Reardon, T. (2005). Private agri-food standards: Implications for food policy and the agri-food system. Food Policy, 30(3), 241-253.

Imbens, G. W., \& Angrist, J. D. (1994). Identification and Estimation of Local Average Treatment Effects. Econometrica, 62(2), 467-475.

Imbens, G. W., \& Wooldridge, J. M. (2009). Recent Developments in the Econometrics of Program Evaluation. Journal of Economic Literature, 47(1), 5-86. doi:10.1257/jel.47.1.5

Jaffee, S., \& Masakure, O. (2005). Strategic use of private standards to enhance international competitiveness: Vegetable exports from Kenya and elsewhere. Food Policy, 30(3), 316-333.

Kersting, S., \& Wollni, M. (2012). New institutional arrangements and standard adoption: Evidence from small-scale fruit and vegetable farmers in Thailand. Food Policy, 37(4), 452-462. doi:10.1016/j.foodpol.2012.04.005

Key, N., \& Runsten, D. (1999). Contract Farming, Smallholders, and Rural Development in Latin America: The Organization of Agroprocessing Firms and the Scale of Outgrower Production. World Development, 27(2), 381-401. doi:10.1016/S0305750X(98)00144-2

Khandker, S. R., Samad, H. A., Ali, R., \& Barnes, D. F. (2012). Who benefits most from rural electrification? evidence in India (Policy Research Working Paper Series No. 6095). The World Bank. Retrieved from http://ideas.repec.org/p/wbk/wbrwps/6095.html 
Khoi, L. N. D. (2011). Quality Management in the Pangasius Export Supply Chain in Vietnam. University of Groningen, Groningen.

Maertens, M., Minten, B., \& Swinnen, J. (2012). Modern Food Supply Chains and Development: Evidence from Horticulture Export Sectors in Sub-Saharan Africa. Development Policy Review, 30(4), 473-497. doi:10.1111/j.14677679.2012.00585.x

Maertens, M., \& Swinnen, J. F. M. (2009). Trade, Standards, and Poverty: Evidence from Senegal. World Development, 37(1), 161-178.

Matuschke, I., \& Qaim, M. (2009). The impact of social networks on hybrid seed adoption in India. Agricultural Economics, 40(5), 493-505. doi:10.1111/j.15740862.2009.00393.x

Minten, B., Randrianarison, L., \& Swinnen, J. F. M. (2009). Global Retail Chains and Poor Farmers: Evidence from Madagascar. World Development, 37(11), 17281741.

MOLISA. (2011). Setting norms on poor households and households in danger of falling into poverty for the 2011-2015 period. Ministry of Labor, War Invalids and Social Affairs. Retrieved from http://english.molisa.gov.vn/docs/search_VBPL/tabid/344/keyword/poverty/DocT ypeID/-1/PublisherID/-1/language/en-US/Default.aspx

Munshi, K. (2004). Social learning in a heterogeneous population: technology diffusion in the Indian Green Revolution. Journal of Development Economics, 73(1), 185213.

Narrod, C., Roy, D., Okello, J. J., Avendaño, B., Rich, K., \& Thorat, A. (2009). Publicprivate partnerships and collective action in high value fruit and vegetable supply chains. Food Policy, 34(1), 8-15. doi:10.1016/j.foodpol.2008.10.005

Neven, D., Odera, M. M., Reardon, T., \& Wang, H. (2009). Kenyan Supermarkets, Emerging Middle-Class Horticultural Farmers, and Employment Impacts on the Rural Poor. World Development, 37(11), 1802-1811.

OECD. (2009). What are Equivalence Scales? OECD. Retrieved from http://www.oecd.org/social/soc/OECD-Note-EquivalenceScales.pdf

Okello, J. J., \& Swinton, S. M. (2007). Compliance with International Food Safety 
Standards in Kenya's Green Bean Industry: Comparison of a Small- and a Largescale Farm Producing for Export. Review of Agricultural Economics, 29(2), 269285.

Phuong, N. T., \& Oanh, D. T. (2010). Striped catfish aquaculture in Viet Nam: A decade of unprecedented development. In Sena S. De Silva \& F. Brian Davy (Eds.), Success Stories in Asian Aquaculture (pp. 131-147). Dordrecht, Netherlands: Springer.

Rao, E. J. O., \& Qaim, M. (2011). Supermarkets, Farm Household Income, and Poverty: Insights from Kenya. World Development, 39(5), 784-796. doi:10.1016/j.worlddev.2010.09.005

Reardon, T., Barrett, C. B., Berdegué, J. A., \& Swinnen, J. F. M. (2009). Agrifood Industry Transformation and Small Farmers in Developing Countries. World Development, 37(11), 1717-1727.

Reardon, T., Codron, J.-M., Busch, L., Bingen, J., \& Harris, C. (1999). Global change in agrifood grades and standards: agribusiness strategic responses in developing countries. The International Food and Agribusiness Management Review, 2(3-4), 421-435.

Reardon, T., \& Farina, E. M. M. Q. (2002). The rise of private food quality and safety standards: illustrations from Brazil. Management, 4(4), 413-421.

Scott, S., Miller, F., \& Lloyd, K. (2006). Doing Fieldwork in Development Geography: Research Culture and Research Spaces in Vietnam. Geographical Research, 44(1), 28-40. doi:10.1111/j.1745-5871.2006.00358.x

SFP. (2012). Pangasius AIP. Sustainable Fisheries Partnership: Vietnamese Pangasius Aquaculture Improvement Project. Retrieved March 25, 2013, from http://www.sustainablefish.org/aquaculture-improvement/pangasius/pangasiusaquaculture-improvement-partnership

Stock, J. H., \& Yogo, M. (2005). Testing for Weak Instruments in Linear IV Regression. In Identification and Inference for Econometric Models. Cambridge, MA: Cambridge University Press. Retrieved from http://dx.doi.org/10.1017/CBO9780511614491

Suri, T. (2011). Selection and Comparative Advantage in Technology Adoption. 
Econometrica, 79(1), 159-209.

Suzuki, A., Jarvis, L. S., \& Sexton, R. J. (2011). Partial Vertical Integration, Risk Shifting, and Product Rejection in the High-Value Export Supply Chain: The Ghana Pineapple Sector. World Development, 39(9), 1611-1623. doi:10.1016/j.worlddev.2011.02.007

Tuan, L. Q. (2003). Country Case Study: Trade in Fisheries and Human Development Vietnam (p. 47). Hanoi: UNDP Asia Pacific Regional Initiative on Trade, Economic Governance and Human Development.

VASEP. (2011). Positive change in Pangasius quality. Vietnam Seafood News. Retrieved March 18, 2012, from http://vietnamseafoodnews.com/?p=2281

VASEP. (2012). Pangasius 26 Q\&A. Hanoi: Agricultural Publishing House.

Vietnamnews. (2011). Vietnam: Shortages force tra-fish exporters to close. Vietnamnews. Retrieved March 18, 2012, from http://qualasaexpertise.wordpress.com/2011/01/11/vietnam-shortages-force-trafish-exporters-to-close/

Vina Seafood. (2009). An Giang proposes government to reschedule and temporary stop collecting debt from pangasius farmers. Vina Seafood. Retrieved March 18, 2012, from http://www.vinaseafood.com.vn/news_details.php?cid=1\&nid=640 


\section{Appendix}

Table A1. Overview of qualitative interviews

\begin{tabular}{|c|c|c|c|c|c|c|}
\hline Category & Selection criteria & $\begin{array}{c}\text { An } \\
\text { Giang }\end{array}$ & $\begin{array}{l}\text { Can } \\
\text { Tho }\end{array}$ & $\begin{array}{l}\text { Dong } \\
\text { Thap }\end{array}$ & $\begin{array}{l}\text { Ho Chi } \\
\text { Minh City }\end{array}$ & Total \\
\hline $\begin{array}{l}\text { Input } \\
\text { supplier }\end{array}$ & $\begin{array}{l}\text { Supplying inputs, such as fry, } \\
\text { fingerlings, feed, supplements and } \\
\text { veterinary medicines to pangasius farms }\end{array}$ & 0 & 1 & 3 & 1 & 5 \\
\hline Farmer & $\begin{array}{l}\text { Owning or working on a pangasius farm, } \\
\text { applying or not applying standards }\end{array}$ & 0 & 1 & 6 & 0 & 7 \\
\hline Processor & $\begin{array}{l}\text { Employed for a processing company in } \\
\text { managing, technical or quality assurance } \\
\text { positions }\end{array}$ & 8 & 3 & 3 & 0 & 14 \\
\hline Exporter & $\begin{array}{l}\text { Employed for international trading } \\
\text { companies }\end{array}$ & 1 & 1 & 1 & 2 & 5 \\
\hline $\begin{array}{l}\text { Service } \\
\text { providers }\end{array}$ & $\begin{array}{l}\text { Providing various kinds of support to the } \\
\text { sector, e.g. financial services, } \\
\text { consultancy, development projects, } \\
\text { certification }\end{array}$ & 0 & 3 & 1 & 4 & 8 \\
\hline Government & $\begin{array}{l}\text { Staff at different levels of provincial or } \\
\text { commune-level governance responsible } \\
\text { for pangasius sector }\end{array}$ & 0 & 5 & 3 & 0 & 8 \\
\hline Researcher & $\begin{array}{l}\text { Representing various research } \\
\text { institutions and universities who are } \\
\text { involved in research on pangasius sector }\end{array}$ & 0 & 3 & 0 & 2 & 5 \\
\hline Total & & 9 & 17 & 17 & 9 & 52 \\
\hline
\end{tabular}


Table A2. Description of key farmer and household variables

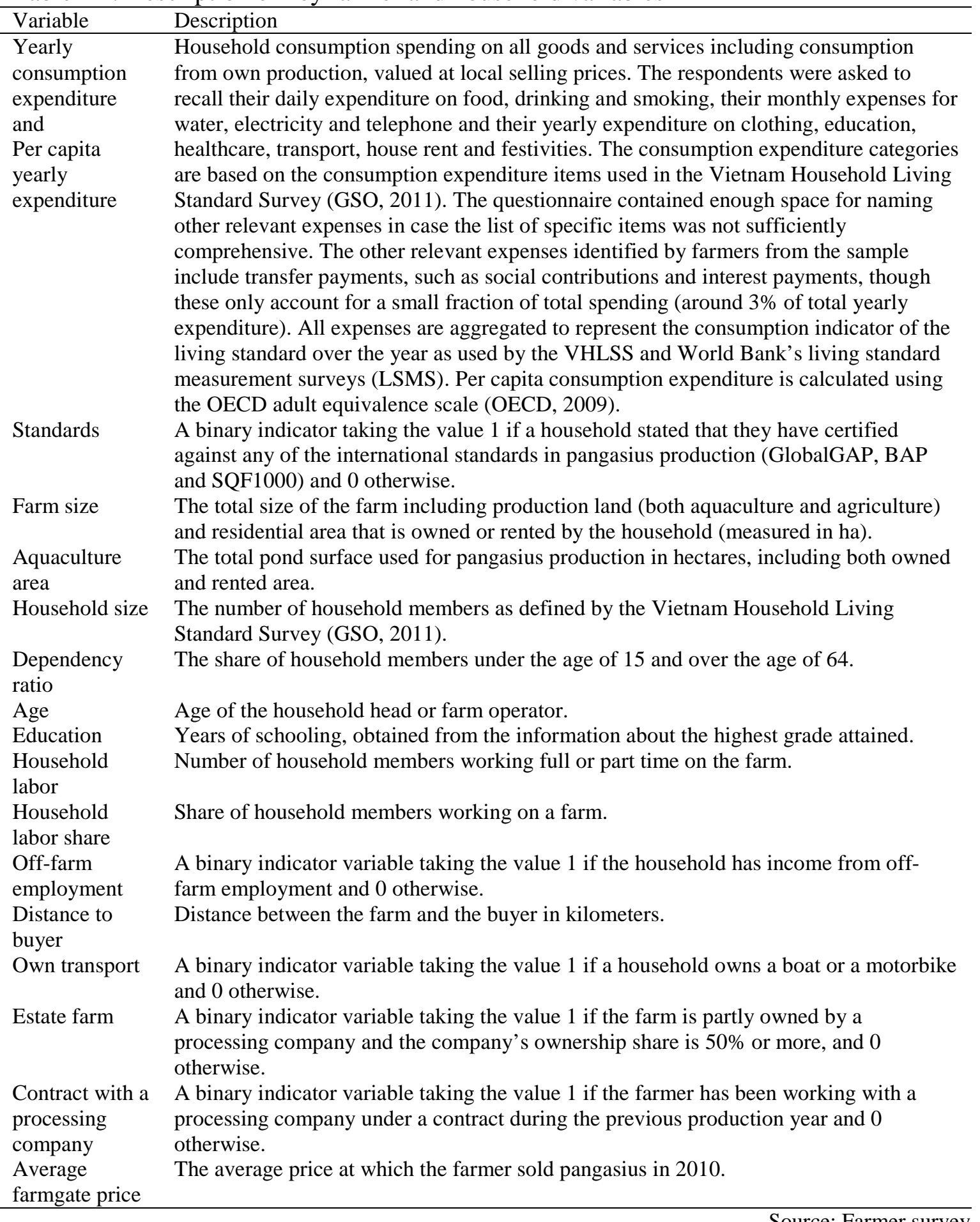

Source: Farmer survey 
Table A3. Average impact of standards on per capita expenditure (log)

\begin{tabular}{|c|c|c|c|c|}
\hline & (1) & (2) & (3) & (4) \\
\hline & OLS & 2SLS IV1 & 2SLS IV2 & 2SLS IV1 and IV2 \\
\hline \multirow[t]{2}{*}{ Standards } & $0.180^{*}$ & $0.443^{*}$ & $0.696 *$ & $0.558^{* *}$ \\
\hline & $(0.104)$ & $(0.257)$ & $(0.420)$ & $(0.241)$ \\
\hline \multirow[t]{2}{*}{ Farm size } & $0.191^{* * *}$ & $0.185^{* * *}$ & $0.179 * * *$ & $0.182 * * *$ \\
\hline & $(0.054)$ & $(0.052)$ & $(0.048)$ & $(0.050)$ \\
\hline \multirow[t]{2}{*}{ Household size } & -0.054 & -0.060 & -0.065 & -0.062 \\
\hline & $(0.040)$ & $(0.038)$ & $(0.041)$ & $(0.039)$ \\
\hline \multirow{2}{*}{ Dependency ratio } & 0.217 & $0.230 *$ & $0.243^{*}$ & $0.236^{*}$ \\
\hline & (0.137) & $(0.136)$ & $(0.125)$ & $(0.131)$ \\
\hline \multirow[t]{2}{*}{ Age } & $0.011^{* *}$ & $0.011^{* *}$ & $0.010^{*}$ & $0.010^{* *}$ \\
\hline & $(0.005)$ & $(0.005)$ & $(0.005)$ & $(0.005)$ \\
\hline \multirow[t]{2}{*}{ Education } & $0.045 * * *$ & $0.042 * * *$ & $0.039 * * *$ & $0.041 * * *$ \\
\hline & $(0.012)$ & $(0.013)$ & $(0.012)$ & $(0.013)$ \\
\hline \multirow[t]{2}{*}{ Household labor share } & $0.145^{* *}$ & $0.153^{* * *}$ & $0.161^{* * *}$ & $0.157 * * *$ \\
\hline & $(0.057)$ & $(0.053)$ & $(0.056)$ & $(0.054)$ \\
\hline \multirow[t]{2}{*}{ Off-farm employment } & -0.147 & -0.127 & -0.107 & -0.118 \\
\hline & $(0.140)$ & $(0.134)$ & $(0.154)$ & $(0.142)$ \\
\hline \multirow[t]{2}{*}{ Distance to buyer (log) } & $-0.085^{* *}$ & $-0.094 * * *$ & $-0.103^{* *}$ & $-0.098 * * *$ \\
\hline & $(0.036)$ & $(0.036)$ & $(0.040)$ & $(0.037)$ \\
\hline \multirow[t]{2}{*}{ Own transport } & 0.001 & -0.047 & -0.093 & -0.068 \\
\hline & $(0.308)$ & $(0.276)$ & $(0.315)$ & $(0.291)$ \\
\hline \multirow[t]{2}{*}{ Estate farm } & 0.167 & 0.142 & 0.118 & 0.131 \\
\hline & $(0.181)$ & $(0.176)$ & $(0.181)$ & $(0.176)$ \\
\hline \multirow[t]{2}{*}{ Contract } & 0.007 & -0.018 & -0.042 & -0.029 \\
\hline & $(0.097)$ & $(0.090)$ & $(0.094)$ & $(0.089)$ \\
\hline \multirow[t]{2}{*}{ An Giang } & $0.478 * * *$ & $0.518 * * *$ & $0.557 * * *$ & $0.536 * * *$ \\
\hline & $(0.163)$ & $(0.152)$ & $(0.172)$ & $(0.158)$ \\
\hline \multirow[t]{2}{*}{ Can Tho } & 0.261 & 0.268 & 0.275 & 0.271 \\
\hline & $(0.298)$ & $(0.276)$ & $(0.273)$ & $(0.275)$ \\
\hline \multirow[t]{2}{*}{ Constant } & $14.08 * * *$ & $14.15^{* * *}$ & $14.22 * * *$ & $14.18^{* * *}$ \\
\hline & $(0.51)$ & $(0.48)$ & $(0.50)$ & $(0.49)$ \\
\hline $\mathrm{N}$ & 270 & 270 & 270 & 270 \\
\hline $\mathrm{R}^{2}$ & 0.236 & 0.224 & 0.192 & 0.212 \\
\hline \multirow{2}{*}{$\begin{array}{l}\text { Hansen } J \text {-test } \\
p \text {-value }\end{array}$} & & & & 0.277 \\
\hline & & & & $(0.599)$ \\
\hline
\end{tabular}

Note: IV1: village-level standards; IV2: heard about standards. Robust standard errors clustered at the commune level in parentheses; ${ }^{*} \mathrm{p}<0.10,{ }^{* *} \mathrm{p}<0.05,{ }^{* * *} \mathrm{p}<0.01$. Source: Farmer survey. 
Table A4. First stage regressions: dependent variable is application of standards

\begin{tabular}{|c|c|c|c|}
\hline & $(1)$ & $(2)$ & (3) \\
\hline \multirow[t]{2}{*}{ Farm size } & 0.028 & 0.028 & 0.032 \\
\hline & $(0.023)$ & $(0.018)$ & $(0.021)$ \\
\hline \multirow[t]{2}{*}{ Household size } & 0.014 & $0.036 * * *$ & $0.028 * * *$ \\
\hline & $(0.009)$ & $(0.010)$ & $(0.009)$ \\
\hline \multirow{2}{*}{ Dependency ratio } & -0.036 & $-0.074 *$ & -0.057 \\
\hline & $(0.047)$ & $(0.042)$ & $(0.049)$ \\
\hline \multirow[t]{2}{*}{ Age } & 0.003 & 0.002 & 0.002 \\
\hline & $(0.002)$ & $(0.002)$ & $(0.002)$ \\
\hline \multirow[t]{2}{*}{ Education } & 0.009 & 0.002 & 0.001 \\
\hline & $(0.008)$ & $(0.007)$ & $(0.007)$ \\
\hline \multirow[t]{2}{*}{ Household labor share } & -0.002 & -0.015 & 0.008 \\
\hline & $(0.040)$ & $(0.045)$ & $(0.034)$ \\
\hline \multirow{2}{*}{ Off-farm employment } & -0.037 & -0.058 & -0.025 \\
\hline & $(0.043)$ & $(0.050)$ & $(0.038)$ \\
\hline \multirow[t]{2}{*}{ Distance to buyer (log) } & 0.016 & 0.022 & 0.007 \\
\hline & $(0.014)$ & $(0.015)$ & $(0.014)$ \\
\hline \multirow[t]{2}{*}{ Own transport } & 0.081 & $0.189 * *$ & 0.096 \\
\hline & $(0.076)$ & $(0.075)$ & $(0.080)$ \\
\hline \multirow[t]{2}{*}{ Estate farm } & $0.113^{*}$ & 0.101 & $0.116^{*}$ \\
\hline & $(0.058)$ & $(0.063)$ & $(0.058)$ \\
\hline \multirow[t]{2}{*}{ Contract } & 0.082 & 0.026 & 0.022 \\
\hline & $(0.059)$ & $(0.065)$ & $(0.051)$ \\
\hline \multirow[t]{2}{*}{ An Giang } & $-0.145^{* *}$ & $-0.221^{* * *}$ & $-0.206^{* * *}$ \\
\hline & $(0.055)$ & $(0.050)$ & $(0.057)$ \\
\hline \multirow[t]{2}{*}{ Can Tho } & 0.077 & -0.045 & 0.051 \\
\hline & $(0.073)$ & $(0.072)$ & $(0.051)$ \\
\hline \multirow[t]{2}{*}{ IV1 } & $0.372 * * *$ & & $0.335^{* * *}$ \\
\hline & $(0.041)$ & & $(0.041)$ \\
\hline \multirow[t]{2}{*}{ IV2 } & & $0.374 * * *$ & $0.331^{* * *}$ \\
\hline & & $(0.047)$ & $(0.047)$ \\
\hline \multirow[t]{2}{*}{ Constant } & $-0.38 * *$ & $-0.41^{* *}$ & $-0.49 * * *$ \\
\hline & $(0.17)$ & $(0.16)$ & $(0.13)$ \\
\hline $\mathrm{N}$ & 270 & 270 & 270 \\
\hline $\mathrm{R}^{2}$ & 0.264 & 0.242 & 0.362 \\
\hline K-P LM statistic & 53.48 & 46.33 & 70.07 \\
\hline K-P Wald F-statistic & 79.43 & 70.30 & 49.29 \\
\hline
\end{tabular}

Note: IV1: village-level standards; IV2: heard about standards. K-P LM and K-P Wald are the KleibergenPaap LM and Wald test statistics for weak instruments. Robust standard errors clustered at the commune level in parentheses; ${ }^{*} \mathrm{p}<0.10,{ }^{* *} \mathrm{p}<0.05,{ }^{* * *} \mathrm{p}<0.01$. Source: Farmer survey. 
Table A5. Average impact of standards on per capita expenditure (log): sample split by farm size

\begin{tabular}{|c|c|c|c|c|c|c|}
\hline & \multirow{2}{*}{\multicolumn{3}{|c|}{$\begin{array}{l}(1) \\
\text { Below median farm size }(1.2 \mathrm{ha})\end{array}$}} & \multirow{2}{*}{\multicolumn{3}{|c|}{$\begin{array}{ccc}(4) & (5) & (6) \\
\text { At and above median farm size }(1.2 \mathrm{ha})\end{array}$}} \\
\hline & & & & & & \\
\hline & IV1 & IV2 & IV1 and IV2 & IV1 & IV2 & IV1 and IV2 \\
\hline \multirow{2}{*}{ Standards } & 0.381 & -0.197 & 0.093 & 0.452 & $1.530 * * *$ & $0.838 * * *$ \\
\hline & $(0.441)$ & $(0.620)$ & $(0.422)$ & $(0.327)$ & $(0.462)$ & $(0.259)$ \\
\hline \multirow[t]{2}{*}{ Farm size } & 0.061 & 0.080 & 0.070 & $0.237 * *$ & $0.213^{*}$ & $0.228 * *$ \\
\hline & $(0.150)$ & $(0.143)$ & $(0.145)$ & $(0.106)$ & $(0.120)$ & (0.109) \\
\hline \multirow[t]{2}{*}{ Household size } & -0.075 & -0.064 & -0.069 & -0.053 & $-0.075 *$ & -0.061 \\
\hline & $(0.090)$ & $(0.089)$ & (0.090) & (0.043) & $(0.043)$ & $(0.042)$ \\
\hline \multirow{2}{*}{$\begin{array}{l}\text { Dependency } \\
\text { ratio }\end{array}$} & -0.436 & -0.490 & -0.463 & $0.301^{* * *}$ & $0.340^{* * *}$ & $0.315^{* * *}$ \\
\hline & (0.377) & (0.299) & $(0.331)$ & (0.089) & $(0.078)$ & $(0.081)$ \\
\hline \multirow[t]{2}{*}{ Age } & $0.013^{* *}$ & $0.013 * * *$ & $0.013 * * *$ & 0.009 & 0.006 & 0.008 \\
\hline & $(0.005)$ & $(0.004)$ & $(0.005)$ & (0.008) & $(0.007)$ & $(0.007)$ \\
\hline \multirow[t]{2}{*}{ Education } & $0.034 * *$ & $0.033^{* *}$ & $0.033^{* *}$ & $0.045^{*}$ & 0.021 & 0.036 \\
\hline & (0.015) & $(0.014)$ & $(0.014)$ & (0.023) & (0.025) & (0.023) \\
\hline Household & 0.083 & 0.072 & 0.077 & $0.177 * * *$ & $0.199 * *$ & $0.185^{* * *}$ \\
\hline labor share & (0.192) & (0.189) & (0.183) & $(0.064)$ & $(0.088)$ & (0.069) \\
\hline Off-farm & -0.124 & -0.207 & -0.165 & 0.004 & -0.004 & 0.001 \\
\hline employment & (0.187) & $(0.228)$ & $(0.204)$ & (0.186) & $(0.221)$ & (0.189) \\
\hline Distance to & $-0.066 * * *$ & -0.052 & $-0.059 * *$ & $-0.120 *$ & $-0.165^{* *}$ & $-0.136 * *$ \\
\hline buyer (log) & $(0.024)$ & (0.033) & $(0.027)$ & $(0.061)$ & $(0.070)$ & $(0.062)$ \\
\hline \multirow[t]{2}{*}{ Own transport } & -0.126 & 0.044 & -0.041 & 0.003 & -0.102 & -0.035 \\
\hline & $(0.206)$ & $(0.257)$ & (0.208) & $(0.466)$ & $(0.504)$ & $(0.472)$ \\
\hline \multirow{2}{*}{ Estate farm } & 0.015 & 0.043 & 0.029 & 0.187 & 0.096 & 0.154 \\
\hline & $(0.155)$ & $(0.162)$ & (0.154) & (0.269) & $(0.290)$ & $(0.271)$ \\
\hline \multirow[t]{2}{*}{ Contract } & 0.014 & 0.076 & 0.045 & 0.006 & -0.105 & -0.034 \\
\hline & (0.117) & $(0.170)$ & (0.137) & (0.165) & (0.157) & (0.149) \\
\hline \multirow[t]{2}{*}{ An Giang } & $0.755^{* * *}$ & $0.631^{* *}$ & $0.693 * * *$ & 0.305 & $0.432 * *$ & $0.350^{*}$ \\
\hline & $(0.184)$ & $(0.257)$ & $(0.210)$ & (0.205) & $(0.217)$ & $(0.205)$ \\
\hline \multirow[t]{2}{*}{ Can Tho } & 0.200 & 0.194 & 0.197 & 0.345 & 0.371 & 0.354 \\
\hline & (0.219) & (0.174) & (0.195) & $(0.516)$ & $(0.465)$ & $(0.494)$ \\
\hline \multirow[t]{2}{*}{ Constant } & $14.38 * * *$ & $14.30 * * *$ & $14.34 * * *$ & $14.01^{* * *}$ & $14.41^{* * *}$ & $14.15^{* * *}$ \\
\hline & $(0.45)$ & $(0.46)$ & $(0.44)$ & $(0.76)$ & $(0.73)$ & $(0.72)$ \\
\hline $\mathrm{N}$ & 135 & 135 & 135 & 135 & 135 & 135 \\
\hline $\mathrm{R}^{2}$ & 0.114 & 0.192 & 0.172 & 0.226 & 0.070 & 0.209 \\
\hline $\begin{array}{l}\text { K-P LM } \\
\text { statistic }\end{array}$ & 20.29 & 22.61 & 27.99 & 32.84 & 19.95 & 38.66 \\
\hline $\begin{array}{l}\text { K-P Wald } F- \\
\text { statistic }\end{array}$ & 26.94 & 29.61 & 17.71 & 55.68 & 34.25 & 30.70 \\
\hline Hansen $J$-test & & & 0.753 & & & 2.849 \\
\hline$p$-value & & & $(0.386)$ & & & $(0.091)$ \\
\hline
\end{tabular}

Note: IV1: village-level standards; IV2: heard about standards. K-P LM and K-P Wald are the KleibergenPaap LM and Wald test statistics for weak instruments. Robust standard errors clustered at the commune level in parentheses; ${ }^{*} \mathrm{p}<0.10,{ }^{* *} \mathrm{p}<0.05,{ }^{* * *} \mathrm{p}<0.01$. Source: Farmer survey. 
Table A6. Frequency of responses for not adopting food standards

\begin{tabular}{lcccccc}
\hline & \multicolumn{7}{c}{ Quantile (\%) } \\
Reasons for not adopting standards & 15 & 25 & 50 & 75 & 85 & 95 \\
\hline Lack of competence/experience & 0.33 & 0.14 & 0.50 & 0.32 & 0.55 & 0.44 \\
Impracticality & 0.17 & 0.14 & 0.19 & 0.28 & 0.09 & 0.33 \\
No consultancy capacity & 0.08 & 0.29 & 0.08 & 0.12 & & 0.11 \\
Not aware of benefits & 0.08 & 0.29 & 0.31 & 0.08 & 0.09 & 0.22 \\
Costs of consultancy & 0.17 & & 0.08 & 0.08 & 0.09 & 0.33 \\
Not demanded locally & 0.08 & 0.14 & 0.08 & 0.08 & & 0.11 \\
Not demanded in foreign markets & & & & 0.04 & & \\
No management commitment & & & 0.04 & & & 0.11 \\
Low commercial return & 0.08 & 0.14 & & 0.04 & & \\
It takes long time to obtain certificate & 0.08 & & 0.04 & 0.08 & & \\
Establishment upgrade costs & 0.50 & 0.43 & 0.42 & 0.32 & 0.55 & 0.67 \\
Cost of certification & 0.17 & 0.14 & 0.08 & 0.28 & 0.45 & 0.22 \\
Do not need & & 0.14 & 0.08 & & & \\
Farm not suitable & & 0.14 & 0.04 & & & \\
Financially constrained & 0.17 & 0.14 & 0.04 & 0.16 & 0.27 & \\
New farm (too early for standards) & & & & & 0.09 & \\
Number of farmers per quantile if S=0 & 12 & 7 & 26 & 25 & 11 & 9 \\
\hline Not Tarle rep
\end{tabular}

Note: Table reports the most important reasons for adopting standards for household-owned farms. Farmers first responded to the question: Why did you decide against standard implementation? after which they chose three most important reasons for not adopting standards, 1 being the most important reason and 3 being the least important. Table reports the frequency of motives for adopting standards divided by the number of farmers in each quantile. Source: Farmer survey. 
Table A7. The most important reasons for adopting food standards

\begin{tabular}{lcccccc}
\hline & \multicolumn{7}{c}{ Quantile (\%) } \\
Reasons for adopting standards & 15 & 25 & 50 & 75 & 85 & 95 \\
\hline To increase export & 1 & 1 & 1 & 1 & 1 & 1 \\
To enhance product quality & & 1 & 1 & 1 & & 1 \\
To meet international market requirements & & 1 & 1 & 1 & & 1 \\
To sell in better-paying markets & 1 & 1 & 1 & 1 & 1 & \\
To decrease occurrence of fish diseases & & 1 & 1 & 1 & & 1 \\
To meet domestic client requirements & & & & 1 & 1 & \\
To sell at higher price & & & & 1 & & \\
To improve reputation & & & 1 & & & \\
To reduce production costs & & & & & & \\
\end{tabular}

Note: The Table reports the most important reasons for adopting standards. Farmers first responded to the question: Why did you decide to start applying standards in your production? after which they chose three most important reasons for adopting standards, 1 being the most important reason and 3 being the least important. The Table reports the motives that were chosen as the most important at least once. Source: Farmer survey. 